\title{
Charnockitic magmatism in southern India
}

\author{
H M RAJESH ${ }^{1 *}$ and M SANTOSH ${ }^{2}$ \\ ${ }^{1}$ Department of Geographical Sciences and Planning, University of Queensland, St Lucia, 4072 Queensland, \\ Australia. \\ ${ }^{2}$ Department of Natural Environmental Science, Faculty of Science, Kochi University, Kochi 780-8520, Japan. \\ *e-mail: rajeshuu@yahoo.com
}

Large charnockite massifs cover a substantial portion of the southern Indian granulite terrain. The older (late Archaean to early Proterozoic) charnockites occur in the northern part and the younger (late Proterozoic) charnockites occur in the southern part of this high-grade terrain. Among these, the older Biligirirangan hill, Shevroy hill and Nilgiri hill massifs are intermediate charnockites, with Pallavaram massif consisting dominantly of felsic charnockites. The charnockite massifs from northern Kerala and Cardamom hill show spatial association of intermediate and felsic charnockites, with the youngest Nagercoil massif consisting of felsic charnockites. Their igneous parentage is evident from a combination of features including field relations, mineralogy, petrography, thermobarometry, as well as distinct chemical features. The southern Indian charnockite massifs show similarity with high-Ba-Sr granitoids, with the tonalitic intermediate charnockites showing similarity with high-Ba-Sr granitoids with low $\mathrm{K}_{2} \mathrm{O} / \mathrm{Na}_{2} \mathrm{O}$ ratios, and the felsic charnockites showing similarity with high-Ba-Sr granitoids with high $\mathrm{K}_{2} \mathrm{O} / \mathrm{Na}_{2} \mathrm{O}$ ratios. A two-stage model is suggested for the formation of these charnockites. During the first stage there was a period of basalt underplating, with the ponding of alkaline mafic magmas. Partial melting of this mafic lower crust formed the charnockitic magmas. Here emplacement of basalt with low water content would lead to dehydration melting of the lower crust forming intermediate charnockites. Conversely, emplacement of hydrous basalt would result in melting at higher $\mathrm{f}_{\mathrm{H}_{2} \mathrm{O}}$ favoring production of more siliceous felsic charnockites. This model is correlated with two crustal thickening phases in southern India, one related to the accretion of the older crustal blocks on to the Archaean craton to the north and the other probably related to the collision between crustal fragments of East and West Gondwana in a supercontinent framework.

\section{Introduction}

Charnockites characterized by orthopyroxenebearing granitic mineral assemblages are a common constituent of granulite-facies metamorphic terrains. However, the relative importance of igneous versus metamorphic processes involved in their origin is debated. They are either granitic rocks metamorphosed to the granulite facies (metamorphic charnockites; e.g., Newton et al 1980) or rocks whose pyroxene crystallized directly from magma (igneous charnockites; e.g., Wendlandt 1981). For example, in Limpopo Belt, South Africa, Bohlender et al (1992) proposed in situ biotite dehydration to form orthopyroxene in the presence of a fluid phase with locally different activity of $\mathrm{CO}_{2}$ for the metamorphic charnockite and crystallization from calc-alkaline magmas derived by partial melting of lower crustal rocks for the spatially associated igneous charnockite.

Charnockitic rocks usually show spatial association of rocks (charnockite-charnoenderbiteenderbite) differing in modal abundance of the dominant feldspar species. There is a

Keywords. Charnockitic magmatism; southern India; intermediate charnockite; felsic charnockite; petrogenetic model. 

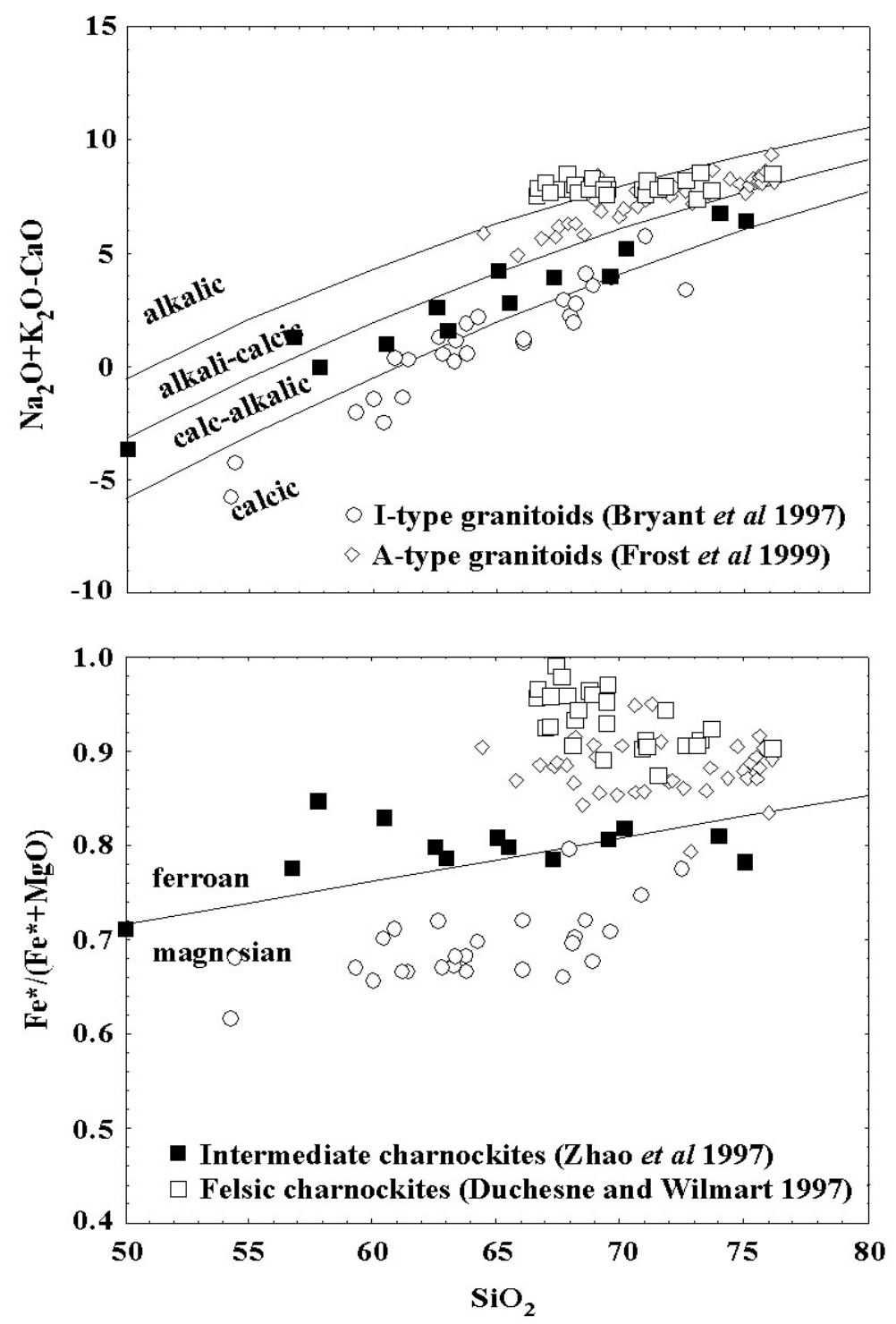

Figure 1. $\mathrm{Fe}^{*} /\left(\mathrm{Fe}^{*}+\mathrm{MgO}\right)$ vs. $\mathrm{SiO}_{2}$ and $\mathrm{Na}_{2} \mathrm{O}+\mathrm{K}_{2} \mathrm{O}-\mathrm{CaO}$ vs. $\mathrm{SiO}_{2}$ plots illustrating the representative trends of I-type granitoids, A-type granitoids, intermediate charnockites, and felsic charnockites.

great deal of scientific literature covering the charnockite (opx-bearing granite)-charnoenderbite (opx-bearing granodiorite)-enderbite (opx-bearing tonalite) (Holland 1900; Tilley 1936; Le Maitre 2002) suite of rocks although no consensus exists about the origin of at least some charnockite occurrences including classic localities. A case of ongoing uncertainty is the origin of arrested charnockite in the Chilka Lake area, India. Dobmeier and Raith (2000) postulated that these rocks formed as a result of localized synkinematic fluid migration and were genetically linked to the host leptynite (garnet-biotite gneiss) in which they are enclosed. These authors also proposed that the charnockites are completely unrelated to enderbite layers in the same outcrops. In a comment, Bhattacharya and Sen (2002) claimed that many rocks interpreted by Dobmeier and Raith (2000) as enderbite are, in reality, charnockites or charnoenderbites. Hence, Bhattacharya and Sen (2002) proposed a common origin for charnockite and enderbite at Chilka Lake.

Charnockites, like granitoids, have a common compositional range and can be broadly divided into intermediate charnockites and felsic charnockites, with most reported occurrences showing variation from intermediate to felsic compositions (Rajesh 2004b). Intermediate charnockites are dominantly calc-alkalic (in terms of modified alkalilime index) and ferroan to magnesian (in terms of Fe-number), while felsic charnockites are dominantly alkali-calcic and ferroan (figure 1). The relatively iron-enriched nature of felsic charnockites imparts to them a predominantly tholeiitic 


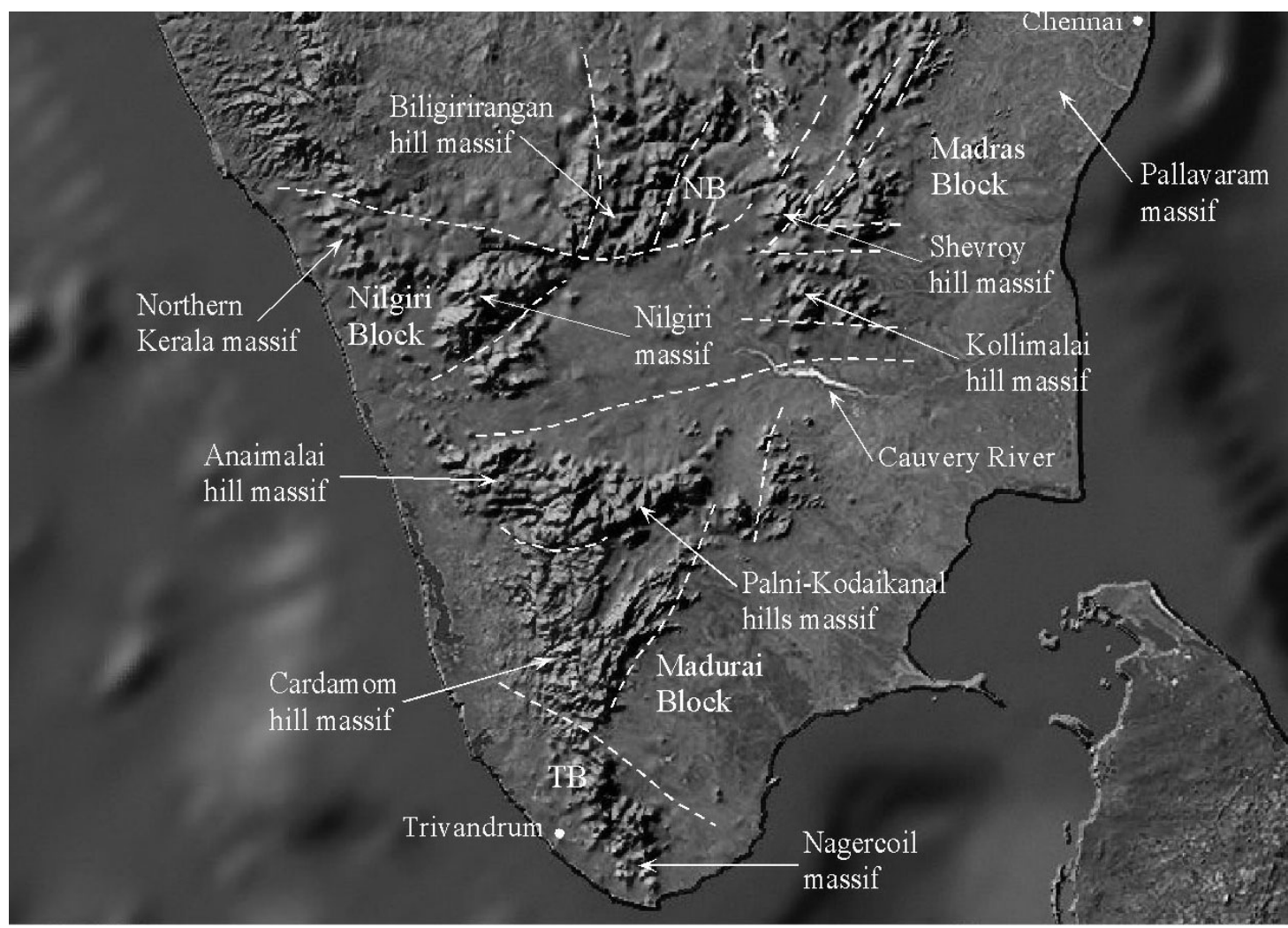

Figure 2. Shaded relief image of southern India showing the distribution of major charnockite massifs (cf. Rajesh 2004b, c). Not all charnockite massifs are considered in this study. The different crustal blocks are also shown. TB - Trivandrum Block; NB - Northern Block.

affinity, in contrast to the predominantly calcalkaline affinity of the intermediate charnockites (Rajesh 2004b).

The formation of charnockites may provide important constraints in trying to unravel the mechanisms involved in granulite formation, because their granitic and often undepleted chemistry, which is more akin to the melt fraction rather than the restite, precludes their formation by removal of a hydrous partial melt. As discussed by Kilpatrick and Ellis (1992), the high temperature origin of charnockites compared to Itype granitoids, together with their more enriched incompatible element abundances, clearly excludes the possibility that they represent the remelting of granulitic residues formed after the extraction of Itype granitoids, a model proposed for the origin of A-type granitoids by Collins et al (1982). Generation of charnockite magmas by high-temperature, water-deficient melting of mafic to intermediate, high-K sources compositionally similar to alkaline basalts or calc-alkaline basaltic andesites is one of the alternatives (e.g., Rajesh 2004a).

In the granulite-facies terrain of southern India, charnockites include intrusions of gabbroic and tonalitic-enderbitic composition occurring over large areas (massif igneous charnockites), massive metamorphic charnockites showing relict compositional banding and obliteration of foliation with the adjacent gneiss, to patches and veins of charnockite (incipient charnockites), representing in situ stages of granulite formation driven by the influx of $\mathrm{CO}_{2}$-rich fluids (carbonic metamorphism; Newton et al 1980). The aim of this paper is to focus on the characteristics of the magmatic charnockites (charnockite hereafter, unless otherwise mentioned) that constitute the major granulite masses in southern India. In the process we compile geochemical data of these massifs to discuss and develop an understanding of how geochemical characteristics relate to their source rocks, petrogenetic processes and tectonic environments.

\section{Geologic setting}

The southern granulite terrain (south of Dharwar craton) includes several regional en echelon Neoproterozoic shear zones which dissect the terrain into different Late Archaean and Proterozoic crustal blocks such as the Madras, Northern, Nilgiri, Madurai and Trivandrum blocks (Harris et al 1994) (figure 2). The northern part of the southern granulite terrain consists primarily of charnockite 
massifs that form highland areas interspersed with lowlands consisting of felsic rocks generally in amphibolite facies (the Madras, Northern, and Nilgiri blocks). The nature of contacts between highland and lowland rocks is highly controversial, with faults suggested, but not proved, at many of the boundaries of the massifs. With the exception of granitoids, carbonatites, and ultramafic rocks, Pan-African ages are absent from the northern part of this granulite terrain. Granulitefacies metamorphism affected the area at ca. $2.5 \mathrm{Ga}$ and 2.8-3.0 Ga. The Nilgiri block was metamorphosed under medium-high pressure $(6-10 \mathrm{kbar}$; Harris et al 1982; Janardhan et al 1982; Raith et al 1990) granulite facies conditions, while Northern and Madras block was metamorphosed under slightly lower pressures (7.5-8 kbar (Janardhan et al 1982; Condie and Allen 1984; Rao et al 1991) and 6.5-7.5 kbar (Bhattacharya and Sen 1986), respectively) at ca. $2.5 \mathrm{Ga}$ (Griffiths et al 1987; Jayananda and Peucat 1996). A noteworthy feature of the granulite-facies transition zone, north of the Biligirirangan hills, is the occurrence of discrete veins and nebulous patches of incipient (metamorphic) charnockites (Pichamuthu 1960; Friend 1981; Janardhan et al 1982; Stahle et al 1987; Naha et al 1993). The non-garnetiferous charnockites of the Biligirirangan hill massif probably form the oldest charnockite massif in southern India. The magmatic protoliths of the charnockites from the Biligirirangan hills accreted at $3.47 \mathrm{Ga}$ (see Jayananda and Peucat 1996). Mahabaleswar et al (1995) and Mojzsis et al (2003) presented zircon ages of $2.96 \mathrm{Ga}$ for magmatic protoliths of charnockites from the northern fringes of Biligirirangan hill massif. Vinogradov et al (1964), Crawford (1969), and Griffiths et al (1987) reported 2.55-2.6 Ga ages for charnockites from the Madras block. Similar ages $(2.5-2.6 \mathrm{Ga})$ have been reported for charnockites from the Nilgiri and Shevroy hill massifs (Spooner and Fairbairn 1970; Peucat et al 1993; Jayananda and Peucat 1996; Raith et al 1999). These charnockite massifs together represent a stage of late Archaean to early Proterozoic juvenile magmatism in the northern part of southern Indian granulite terrain. Nd-model ages from the Biligirirangan hill range from $3.2-3.6 \mathrm{Ga}$ (Jayananda and Peucat 1996), those from the Shevroy hill range from 2.7-2.9 Ga (Peucat et al 1989), those from the Madras block range from 2.35-2.8 Ga (Griffiths et al 1987), and those from the Nilgiri block range from 2.6-2.9 Ga (Peucat et al 1989; Raith et al 1999).

The southern part of the granulite terrain contains the same type of highland charnockite massifs (Madurai block) and lowland gneisses as the area north of the zone. In contrast to the northern part of the granulite terrain, the area south of Palghat-Cauvery shear zone contains ample evidence for Pan-African activity (metamorphism and magmatism). Compared to the older charnockite massifs from Madras-Northern-Nilgiri blocks, the Madurai and Trivandrum blocks expose early- to late-Proterozoic charnockite massifs (Bartlett et al 1995; Jayananda et al 1995; Miller et al 1996; Mohan and Jayananda 1999). Recent studies from Madurai block have suggested a polymetamorphic and multistage P-T $\left(700-1000^{\circ} \mathrm{C}\right.$ and $5-12 \mathrm{kbar}$; Harris et al 1982; Mohan and Windley 1993; Raith et al 1997; Satish Kumar et al 2002) evolution for the terrane. Nd-model ages from the Madurai block range from 2.1-3.1 Ga (Harris et al 1994; Bartlett et al 1998).

The Achankovil Shear Zone marks the southern limit of the Madurai Block and the northern limit of the Trivandrum Block. The Trivandrum Block is subdivided on lithological grounds into three tectonic units; the Kerala Khondalite Belt (KKB), the Nagercoil unit and the Achankovil metasediments. Single zircon evaporation and EPMA monazite ages suggest that all the three units experienced a thermal event possibly under upper-amphibolite facies at $\sim 1800 \mathrm{Ma}$ (Bartlett et al 1998; Braun et al 1998). This event was overprinted by the granulite facies metamorphism at ca. 540-600 Ma at conditions of $750-1050^{\circ} \mathrm{C}$ and 5-9.5 kbar (Santosh et al 1990; Chacko et al 1996; Kumar and Harley 2000; Cenki et al 2002). The KKB is a predominantly metasedimentary complex characterized by interlayered pelitic and semi-pelitic metasediments and calc-silicates, deposited under shallow marine conditions (Chacko et al 1987). The KKB became well known through its spectacular exposures of incipient (metamorphic) charnockite formation (Hansen et al 1987; Jackson et al 1988; Santosh et al 1990; Raith and Srikantappa 1993; Harley and Santosh 1995; Rajesh 2004a), and was accreted to the lateArchaean and Proterozoic granulite terranes in the north during the Pan-African orogeny (Choudhary et al 1992; Harris et al 1994). The southernmost tip of India is composed of charnockites and charnoenderbites (Nagercoil unit), and geochronologic studies suggested that they experienced a similar crustal history to the KKB. Nd modal ages from the Achankovil metasediments range from 1.3-1.5 Ga, from the KKB range from $2.1-3 \mathrm{Ga}$, and from the Nagercoil unit range from 2.1-2.57 Ga (Harris et al 1994; Brandon and Meen 1995; Warrier et al 1995; Bartlett et al 1998).

\section{Salient field and petrographic features of the charnockite massifs}

From north to south, the charnockite massifs considered here are the Pallavaram, Shevroy hill, 
Biligirirangan hill, Nilgiri hill, northern Kerala, Cardamom hill, and Nagercoil massifs (figure 2). Most of the exposed rocks of these massifs comprise intermediate type (enderbites) and/or felsic type (charnoenderbites to charnockites). Together they cover a substantial portion of the continental crust in southern India. Their greenish to greenishyellow colour in fresh outcrops, unusual for granitic rocks, is due, at least in part, to fine alteration and fracture fillings in the feldspars. Both types usually have a dark greasy homogenous and massive appearance in quarry exposures. Some of the massive charnockite exposures show streaky gneissic foliation and signs of retrogression (retrogressed portions are lighter in colour). On weathered surfaces, the essentially gneissic nature of the rocks becomes evident. The lineation, generally parallel to the foliation, observed in some of the massifs is made conspicuous by the differential weathering of feldspars and quartz. Although all the massifs show overprints of subsequent granulite facies metamorphism, the igneous nature of their protoliths is evident from a combination of some or all of the following features: outcrop pattern, intrusive relationship with the surrounding rocks, homogeneity at outcrop scale, presence of enclaves and xenoliths, cross-cutting charnockitic dikes, in situ development of ( \pm orthopyroxene bearing) pegmatoids, granitic textures, observed order of crystallization of primary minerals, as well as distinct chemical features (see below).

The Pallavaram massif consists mainly of felsic charnockites (charnoenderbites to charnockites) and minor intermediate charnockites (enderbites). Garnet is present in the felsic charnockites. Both the Shevroy hill and Biligirirangan hill massifs consist of intermediate charnockites (enderbites), with the former bearing garnet and the latter garnetfree. When present, garnet usually shows inhomogeneous distribution, sometimes occurring in local lenses and bands. Dark gray bands and lenses of mafic charnockite occur within the Shevroy hill charnockites. The Nilgiri hill massif is composed of intermediate charnockites (minor, but distinct, non-garnetiferous enderbites to dominant garnetiferous enderbites). The garnetiferous enderbites show prominent gneissic layering and are characterized by the compositional and structural uniformity throughout the massif. Dolerite dykes cut across both the Nilgiri hill and Biligirirangan hill massifs. Neoproterozoic shear zones partly bound and separate the Shevroy, Biligirirangan and Nilgiri hill massifs (figure 2). Continuous layers of metasedimentary gneisses (garnet-sillimanite gneiss and minor garnet-biotite gneiss) bound the Pallavaram and Shevroy hill massifs. Within these gneisses, lensoid masses of mafic granulites and calc-silicate rocks, and boudinaged alkali pegmatites are common. Boudinaged enclaves of mafic granulites are common in the massifs, whereas ultramafic and Fe-rich layers are found only in the intermediate massifs. Except the Biligirirangan hill massif, other massifs contain less significant amount of metasedimentary layers/swathes. The rare metasedimentary intercalations in the Nilgiri hill massif include banded magnetite quartzites, kyanite and garnet bearing quartzites, and garnetiferous gneisses. The occurrence of xenoliths (basic (pyroxene- or garnetbearing) granulites, pyroxenites) in the charnockite massifs and the presence of dykes of pyroxenebearing granite cutting amphibolite facies rocks suggests hot, dry magmas.

Dark greenish-gray colored intermediate charnockites (enderbites) form the dominant rock type in the northern Kerala massif. The spatially associated felsic charnockites (charnoenderbites to charnockites) form a minor, but distinct, rock type in the northern Kerala massif. Basic rock enclaves are present in both charnockites. Granitic veins cut across several exposures of the northern Kerala massif, causing retrogression of the host charnockites. The rocks along the retrogressed areas are lighter in color and are mostly devoid of orthopyroxene. They contain amphibole and biotite, which impart gneissosity to the rocks. The northern Kerala massif is bounded by biotitehornblende gneiss/hornblende-biotite gneiss, often carrying boudins and bands (dykes) of amphibolite, and mica schist. Dolerite dykes cut across all the rock types including charnockite.

Like the northern Kerala massif, the Cardamom hill massif is also composed of intermediate and felsic charnockites. A very weak foliation trending NW-SE, imparted by biotite, is seen in some of its charnockite exposures. Metasedimentary rocks in the south and hornblende-biotite gneiss/biotitehornblende gneiss in the north, bound the Cardamom Hill massif. The gneissic exposures in the south show variations from garnet-biotite gneiss to migmatitic garnet gneiss to cordierite gneiss. Some of the gneissic exposures exhibit incipient (metamorphic) charnockitic patches. The Nagercoil charnockite massif is composed of garnetiferous and non-garnetiferous felsic charnockites and is bounded by garnet-biotite gneiss and minor garnetbiotite-sillimanite \pm graphite gneiss. Apart from a weak foliation developed at places, the charnockite generally shows a massive texture. Pyroxene granulite bands, mafic dykes, and metapelite or calc-silicate enclaves occur within the charnockite massif. Some metapelite lenses show very diffuse margins, laterally grading into the host charnockite. Garnet is present only in those areas where the charnockite encloses supracrustal lithologies, and shows pronounced foliation. The gneissic rocks 
show variations from a predominant garnet-biotite gneissic rock, through an intercalated rock of garnet-biotite gneiss and garnet leuco-gneiss, to bands of augen gneiss. Irregular patches $(\sim 0.5$ to $20 \mathrm{~cm}$ ) and veins of charnockite (incipient (metamorphic) charnockite) are spectacularly exposed in some of the garnet-biotite gneiss exposures.

The common mineral assemblage of the Pallavaram and Shevroy hill massifs is qtz-kfs-plgopx \pm cpx \pm grt \pm hbl \pm bt-ap-zr-mt-il-ru-pyrr. The mafic charnockite from the Shevroy hill massif has a dominant mineralogy of plg-cpx-opx-hblmt-il-ru $\pm \mathrm{kfs} \pm$ bt-ap-zr. The non-garnetiferous enderbites from both the Biligirirangan and Nilgiri hill massifs have a similar mineralogy of qtz-plgkfs-cpx-opx \pm hbl \pm bt-ap-zr-mt-il-ru-pyrr. The most commonly encountered mineral assemblage of intermediate type northern Kerala massif is qtzplg-opx-cpx-mt-il-ap-zr \pm kfs \pm hbl \pm bt \pm grt, and that of felsic type northern Kerala massif is qtzkfs-plg-opx \pm cpx-hbl-bt-zr-ap-ru-ti. Garnet accompanies the intermediate type northern Kerala massif occasionally. The felsic type Cardamom hill massif has a dominant mineralogy of qtz-kfs-plgopx-mt-il-zr-ap $\pm \mathrm{hbl} \pm \mathrm{bt}$, while the intermediate type Cardamom hill massif has mineralogy of qtzplg-kfs-opx-cpx \pm hbl \pm bt-mt-il-ru-zr-ap. Nagercoil massif charnockites show a common mineral assemblage of qtz-plg-kfs-opx-bt-il-zr-ap \pm grt. In general the intermediate charnockites are distinguished from felsic charnockites by their relatively low K-feldspar contents, and greater mafic mineral contents. Garnet is usually absent or of small abundance in intermediate charnockites than in the felsic charnockites. The ubiquitous (but quite unevenly distributed) occurrence of perthite, antiperthite and/or coarse mesoperthites, clinopyroxene exsolution and/or pyrrhotite in these rocks is suggestive of the crystallization of the host rock at elevated temperatures.

Compositionally the intermediate Shevroy hill charnockites range from quartz monzodiorite to tonalite and granodiorite, the intermediate Biligirirangan hill and Nilgiri hill charnockites show similar compositional range from tonalite to granodiorite, the intermediate Nilgiri hill charnockites range from quartz diorite to tonalite to granodiorite, the intermediate northern Kerala charnockites range from quartz diorite to tonalite, whereas the intermediate Cardamom hill charnockites range from diorite to quartz monzodiorite in the normative Qz-Or-Ab + An ternary plot. Regarding the felsic charnockites, those from the northern Kerala and Cardamom hill massifs show similar compositional range from granodiorite to monzogranite, while those from the Pallavaram and Nagercoil massifs show similar compositional variation from quartz monzodiorite to granodiorite to monzogranite. In the $Q-P$ cationic classification of Debon and LeFort (1988), they show similar compositional range with the exception of the most felsic samples falling in the granite field; the overall trend of intermediate charnockites being calc-alkaline and felsic charnockites tholeiitic.

\section{Whole-rock geochemical variations}

Howie (1955), Howie and Subramaniam (1957), Subramaniam (1959), Weaver et al (1978), Weaver (1980), Condie et al (1982), Condie and Allen (1984), and Griffiths et al (1987) presented geochemical data on the Pallavaram and Shevroy hill massifs. Except a few intermediate samples $\left(\mathrm{SiO}_{2} \sim 54\right.$ to $\left.59 \mathrm{wt} \%\right)$, the Pallavaram felsic charnockites show high silica content from $\sim 64$ to $77 \mathrm{wt} \%$. The Shevroy intermediate charnockites $\left(\mathrm{SiO}_{2} \sim 54\right.$ to $\left.72 \mathrm{wt} \%\right)$ are characterized by higher contents of $\mathrm{TiO}_{2}, \mathrm{Al}_{2} \mathrm{O}_{3}$, total $\mathrm{Fe}, \mathrm{MgO}, \mathrm{CaO}$, $\mathrm{Na}_{2} \mathrm{O}$ and $\mathrm{P}_{2} \mathrm{O}_{5}$, but lower $\mathrm{K}_{2} \mathrm{O}$ contents than the Pallavaram felsic charnockites. In the normative An-Ab-Or triplot, intermediate charnockite compositions (Shevroy hill and Pallavaram massifs) fall mainly in the tonalite field, while the felsic charnockite compositions (Pallavaram massif) show an extended compositional range up to the granite field (figure 3). Condie and Allen (1984), Janardhan et al (1994), Srikantappa (1996) and Raith et al (1999) presented geochemical data on the Biligirirangan hill and Nilgiri hill intermediate charnockite massifs. The non-garnetiferous charnockites $\left(\mathrm{SiO}_{2} \sim 57\right.$ to $\left.61 \mathrm{wt} \%\right)$ from the Nilgiri hill massif are characterized by higher contents of $\mathrm{TiO}_{2}, \mathrm{Al}_{2} \mathrm{O}_{3}, \mathrm{CaO}, \mathrm{Na}_{2} \mathrm{O}, \mathrm{P}_{2} \mathrm{O}_{5}, \mathrm{Sr}$, and $\mathrm{Ba}$, but lower $\mathrm{Rb}$ contents than the garnetiferous charnockites $\left(\mathrm{SiO}_{2} \sim 63\right.$ to $\left.71 \mathrm{wt} \%\right)$. Raith et al (1999) suggested that the garnetiferous charnockites exhibit dominant compositional features of S-type granitoids, while the non-garnetiferous charnockites exhibit compositional features of Itype granitoids. The overlapping nature of the compositions of I-type and S-type granitoids is now evident worldwide. Even the I-type and Stype granitoid types in the Lachlan Fold Belt, which was originally used by Chappell and White (1974) to propose the S- and I- type granitoid classification, form an overlapping chemical and isotopic array (Collins 1996). Our geochemical discrimination points to the dominant I-type affinity of the Nilgiri hill intermediate charnockites (figures $4 \mathrm{a}, 4 \mathrm{c}$ and $4 \mathrm{~d})$. In this context, it is important to point out that Rajesh (2004b) illustrated the similarity of some intermediate charnockites to the geochemical characteristics of fractionated I-type granitoids, while the geochemical characteristics of felsic charnockites are more comparable to that 


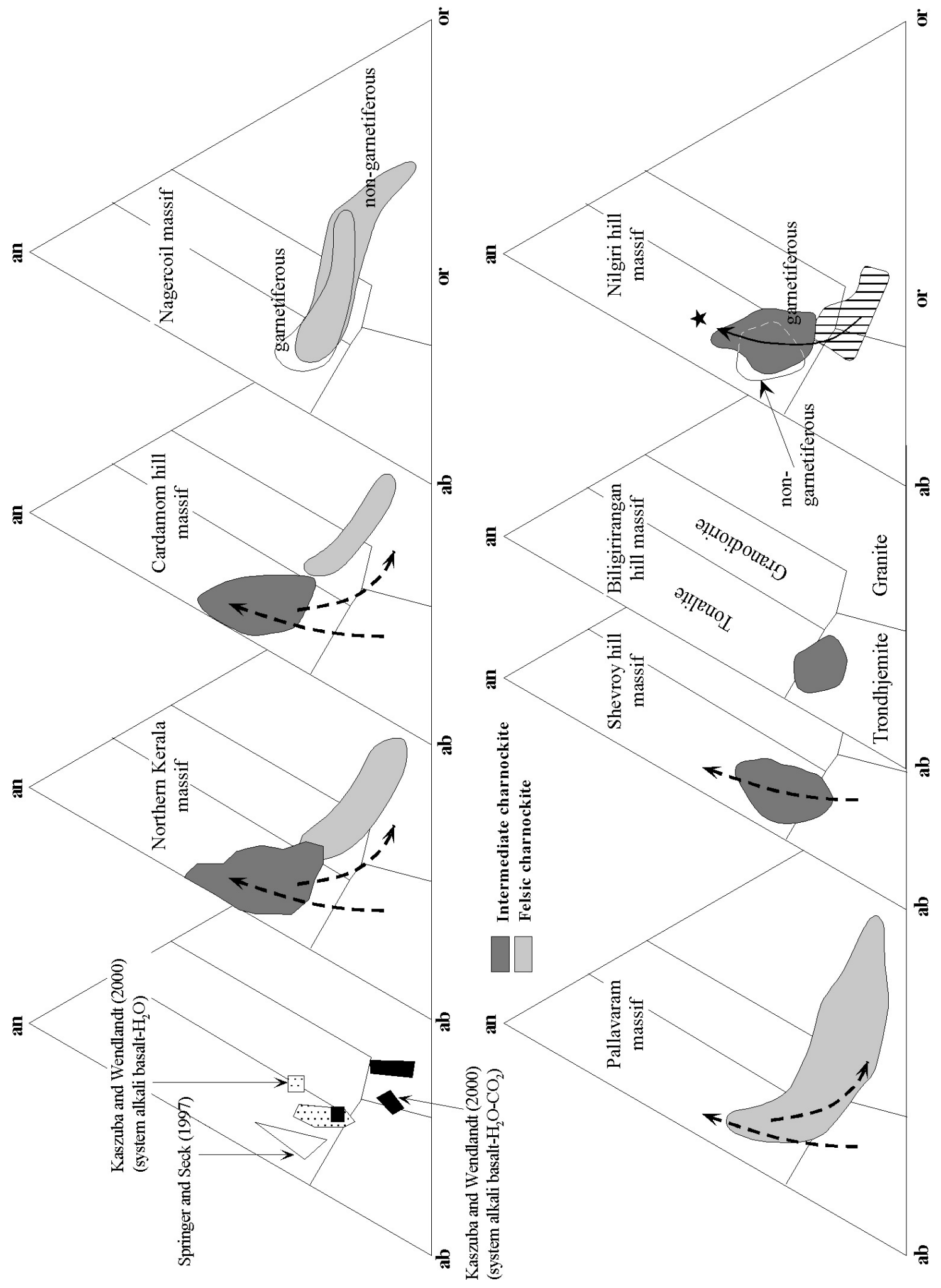

प्र

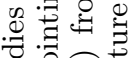

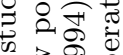

$\infty$ है

记

물

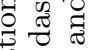

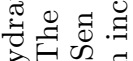

क्ष

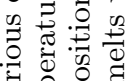

ज़ 웜

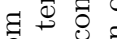

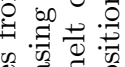

娄

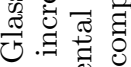

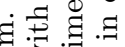

50

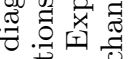

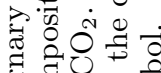

छ

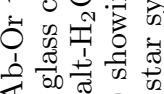

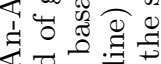

氜 :

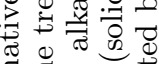

의

:

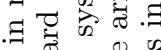

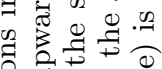

过

율 $0^{3}$ 造

记

फै

ङ

记

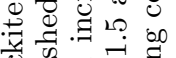

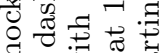

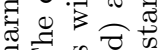

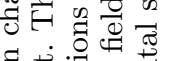

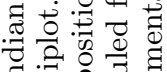

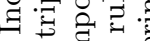

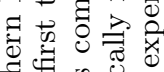

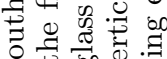

$\overrightarrow{0} \exists+4$

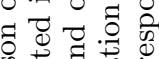

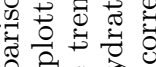

द्व

0.20

के

을 党

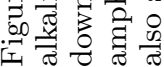



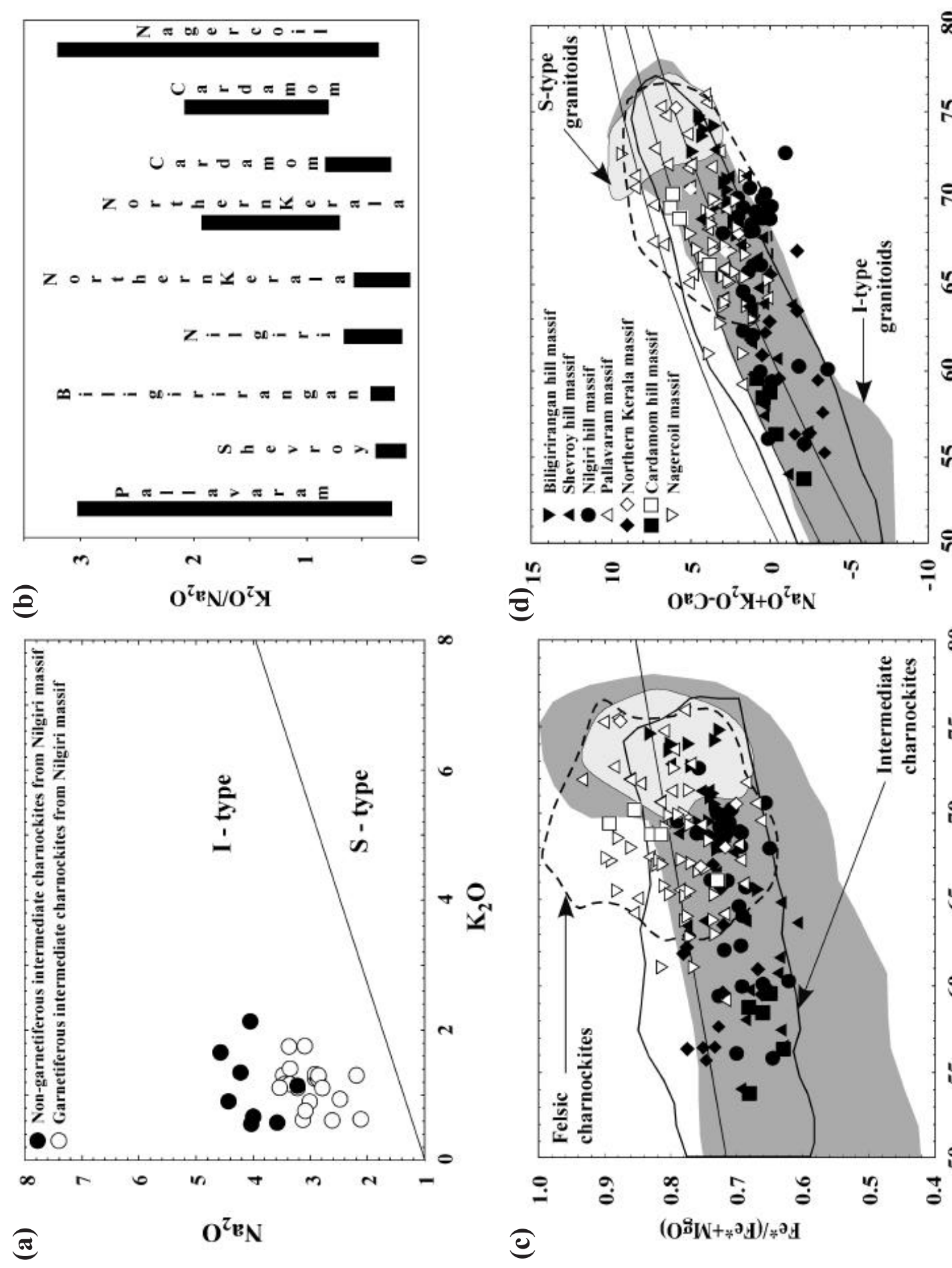

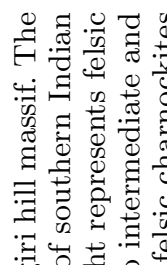

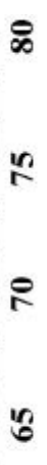

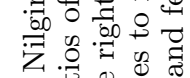

घี ॠ.

4 事

$1 \quad$.

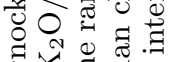

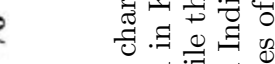

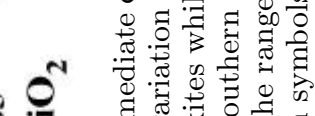

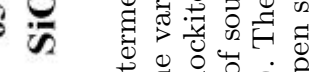

-

$8 \quad 0.0$

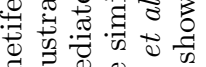

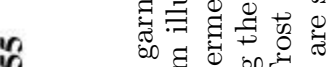

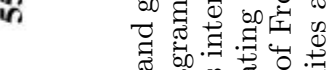

o.

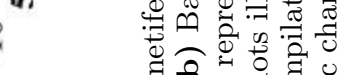

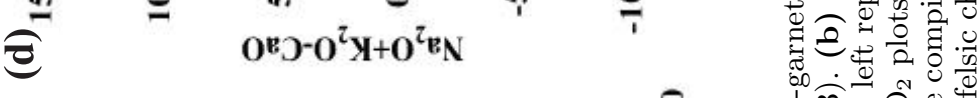

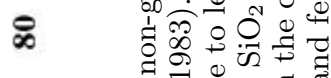

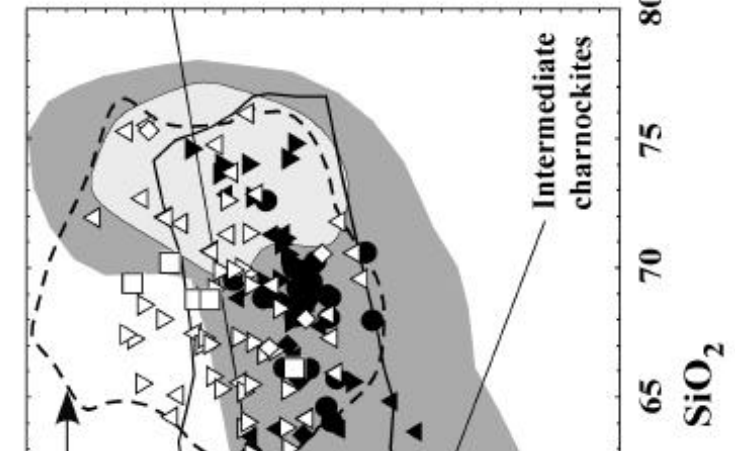

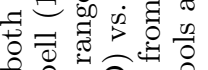

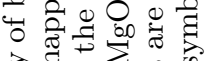

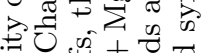

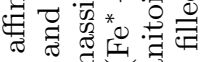
电.

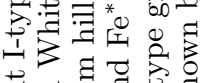

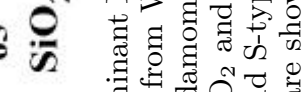

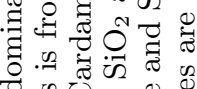

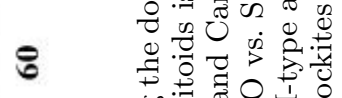
象㱐

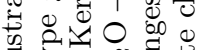

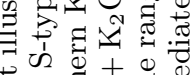

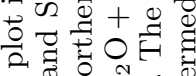

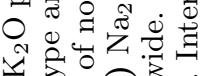
के

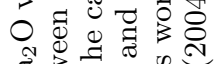

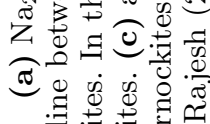
म 00 둥

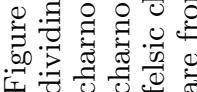


of A-type granitoids, and is often referred to in the literature as A-type charnockites (e.g., Zhou et al 1995). Compositionally, the nongarnetiferous intermediate charnockites from the Nilgiri hill massif fall in the tonalite field while the garnetiferous intermediate charnockites fall in the tonalite-granodiorite fields (figure 3). They exhibit calc-alkaline affinities, with the garnetiferous intermediate charnockite samples falling close to the field boundary of the tholeiitic series. The older non-garnetiferous intermediate charnockites from Biligirirangan massif $\left(\mathrm{SiO}_{2} \sim 68\right.$ to $\left.75 \mathrm{wt} \%\right)$ have lower contents of $\mathrm{TiO}_{2}$, total $\mathrm{Fe}, \mathrm{MgO}$, $\mathrm{Zn}, \mathrm{V}, \mathrm{Cr}$, and higher $\mathrm{Al}_{2} \mathrm{O}_{3}, \mathrm{Na}_{2} \mathrm{O}+\mathrm{K}_{2} \mathrm{O}, \mathrm{Rb}$ than the Nilgiri intermediate charnockites (Condie and Allen 1984; Raith et al 1999). Compositionally, the Biligirirangan intermediate charnockites cluster across the trondhjemite-tonalite field boundary (figure 3) and display a calc-alkaline trend.

Nambiar et al (1992) and Rajesh (2004b) presented geochemical data on the northern Kerala charnockites. Chacko et al (1992) presented geochemical data on the Cardamom hill charnockites. Both the intermediate $\left(\mathrm{SiO}_{2} \sim 53\right.$ to $\left.59 \mathrm{wt} \%\right)$ and felsic $\left(\mathrm{SiO}_{2} \sim 66\right.$ to $\left.69 \mathrm{wt} \%\right)$ Cardamom hill charnockites show similar major and trace element trends as well as compositional ranges (tonalite (intermediate charnockites) to granodiorite-granite (felsic charnockites)) as their northern Kerala massif counterparts (intermediate type $\left(\mathrm{SiO}_{2} \sim 55\right.$ to $67 \mathrm{wt} \%$ ); felsic type $\left(\mathrm{SiO}_{2} \sim 68\right.$ to $75 \mathrm{wt} \%$ )) (figure 3). They display a typical calc-alkaline trend close to the field boundary to the tholeiitic series. Srikantappa et al (1985) and Santosh et al (2004) presented geochemical data on the Nagercoil felsic charnockites. Both the garnetiferous $\left(\mathrm{SiO}_{2} \sim 61\right.$ to $71 \mathrm{wt} \%)$ and non-garnetiferous $\left(\mathrm{SiO}_{2} \sim 62\right.$ to $72 \mathrm{wt} \%$ ) charnockites show similar compositional ranges of tonalite-granodiorite-granite, with the non-garnetiferous charnockite compositions showing an extended range (figure 3). They typically display a calc-alkaline to tholeiitic trend.

In general the intermediate charnockites fall mainly in the tonalite field, while the felsic charnockite compositions show an extended compositional range up to the granite field. Both the intermediate and felsic charnockites from each massif have quite different $\mathrm{K}_{2} \mathrm{O} / \mathrm{Na}_{2} \mathrm{O}$ ratios, with the latter having a higher and extended range than the former (figure 4b). In terms of Fenumber all the intermediate charnockites are magnesian, with felsic charnockites showing magnesian to dominantly ferroan compositions (figure 4c). Although intermediate samples show calc-alkalic to calcic affinity (in terms of the modified alkalilime index), felsic samples show variations from alkali-calcic to calc-alkalic to calcic (figure 4d).
In terms of alumina saturation index, all the charnockite massifs are metaluminous to peraluminous with peraluminous compositions in the high $\mathrm{SiO}_{2}$ samples. The major element characteristics of these charnockite massifs are similar to intermediate and felsic charnockites worldwide (Rajesh 2004b).

Although Condie et al (1982), Condie and Allen (1984), Janardhan et al (1994) and Raith et al (1999) reported significant depletion of $\mathrm{Rb}$ in Archaean charnockites from the northern part of the southern Indian granulite terrain, Subramaniam (1959), Weaver et al (1978) and Weaver (1980) reported Rb enrichment from the Archaean Pallavaram massif. Further Raith et al (1999) also reported $\mathrm{Rb}$ enrichment (with significant $\mathrm{Rb}$ depletion with increase in silica content) from the Archaean Biligirirangan massif, implying that $\mathrm{Rb}$ depletion is not unique in Archaean southern Indian charnockites. The younger charnockite massifs from the Madurai and Trivandrum blocks invariably show $\mathrm{Rb}$ enrichment. Significantly all the charnockite massifs from southern India are rich in $\mathrm{Ba}$ and $\mathrm{Sr}$, similar to high-Ba-Sr granitoids (Tarney and Jones 1994) (figure 5). Generally, the traditional I-, S- and Atype granitoids possess low $\mathrm{Ba}$ and $\mathrm{Sr}$ concentrations (hence, denominated together as low-Ba- $\mathrm{Sr}$ granitoids) (figure 5a). However, Tarney and Jones (1994) identified an additional type, named high-Ba-Sr granitoids, that exhibits many traceelement characteristics distinct from the low-Ba-Sr granitoids. In general intermediate charnockites show similarity to high-Ba-Sr granitoids with low $\mathrm{K}_{2} \mathrm{O} / \mathrm{Na}_{2} \mathrm{O}$ ratios, similar to adakites, while felsic charnockites show similarity to high-Ba$\mathrm{Sr}$ granitoids with high $\mathrm{K}_{2} \mathrm{O} / \mathrm{Na}_{2} \mathrm{O}$ ratios, which are different from adakites (figure $5 \mathrm{~b}$; Rajesh 2004b).

Rare earth element patterns are similar for the different charnockite massifs with slightly fractionated, LREE enriched, and HREE depleted patterns; the main difference being the presence or absence of (positive and/or negative) Eu anomaly. Some of the Biligirirangan hill massif samples show positive Eu anomalies, while the Shevroy hill massif samples show both negative and positive Eu anomalies. The Nilgiri hill non-garnetiferous intermediate charnockites are characterized by the absence of an Eu anomaly, while the garnetiferous variety is characterized by a slightly negative Eu anomaly. Although overall rare earth element concentrations of charnockites from the northern Kerala and Cardamom hill massifs are similar, the latter are distinguished by pronounced negative Eu anomalies, while $\mathrm{Eu}$ anomalies are modest in the former and range from slightly negative to slightly positive. 

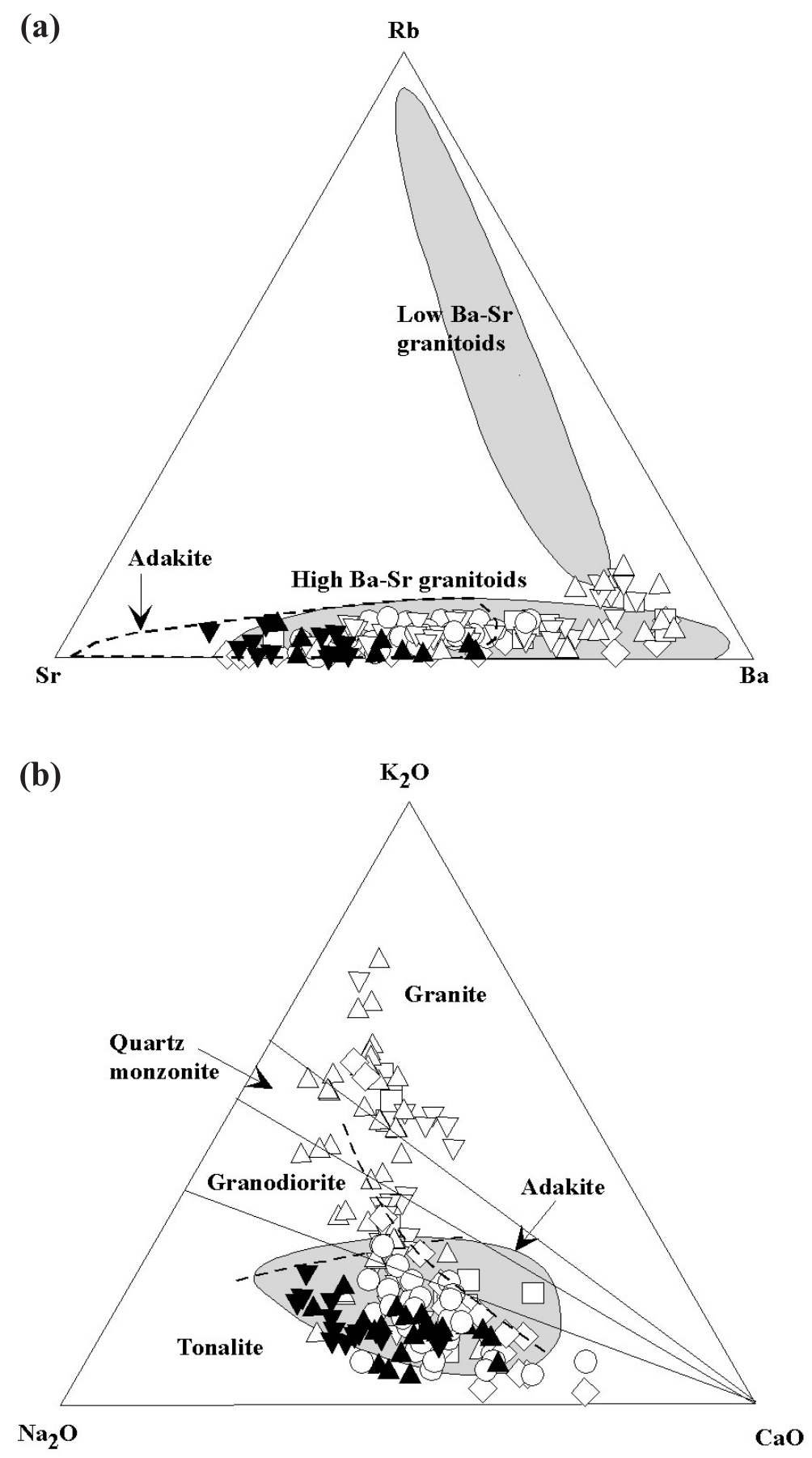

Figure 5. (a) Sr-Rb-Ba and (b) Na-K-Ca triplots for the charnockite massifs from southern India. Same symbology as in figure 4, with intermediate charnockite from different massifs, except Shevroy hill (filled triangle) and Biligirirangan hill (filled down triangle) massifs, shown by open symbols for clarity. Fields of high-Ba-Sr and low-Ba-Sr granitoids are based on data from Fowler and Henney (1996) and Fowler et al (2001). See Rajesh (2004b) for the references on adakite compositions. The dashed line in figure $5 \mathrm{~b}$ running upward indicates calc-alkaline trend, while that running sidewards indicates trondhjemitic trend.

\section{Conditions of crystallization}

The higher $\mathrm{Ti}$ and $\mathrm{P}$, in comparison to spatially associated granitoids (e.g., Rajesh et al 1996; Rajesh 1999, 2000, 2003, 2004a, b) correspond to higher saturation temperatures for Fe-Ti oxides and apatite in the charnockites (Watson and Harrison 1983; Green and Pearson 1986). Temperature estimates based on zircon solubilities in felsic liquids (Watson and Harrison 1983) range from $\sim 953$ to $679^{\circ} \mathrm{C}$ for the Pallavaram massif, $\sim 850$ to $800^{\circ} \mathrm{C}$ for the Biligirirangan hill massif, 
$\sim 857$ to $776^{\circ} \mathrm{C}$ for the Shevroy hill massif, $\sim 1036$ to $778^{\circ} \mathrm{C}$ for the Nilgiri hill massif, $\sim 940$ to $700^{\circ} \mathrm{C}$ for the northern Kerala massif, $\sim 920$ to $750^{\circ} \mathrm{C}$ for the Cardamom hill massif, and $\sim 936$ to $813^{\circ} \mathrm{C}$ for the Nagercoil massif. Crystallization temperatures of $\sim 900$ to $1000^{\circ} \mathrm{C}$ are supported by the high $\mathrm{TiO}_{2}$ and/or $\mathrm{P}_{2} \mathrm{O}_{5}$ contents of the least evolved samples of these massifs. Application of QUILF calculation (Andersen et al 1993) on co-existing pyroxenes (Weaver et al 1978; Rajesh 1999) yielded crystallization temperatures of 840 to $710^{\circ} \mathrm{C}$ and 960 to $860^{\circ} \mathrm{C}$ for the Pallavaram and northern Kerala massifs respectively. Available pressure estimates from these massifs range from 6 to $9 \mathrm{kbar}$ (Condie and Allen 1984; Raith et al 1990; Nambiar et al 1992; Rajesh 1999; Santosh et al 2003).

When compared with liquidus phase relations in the system Q-Ab-Or, the felsic charnockite compositions spread around the minimum. Whilst intermediate charnockitic melts are clearly not minimum melts, they occur parallel to the $\mathrm{Q}-\mathrm{Ab}$ sideline in the Q-Ab-Or plot. The non-garnetiferous intermediate charnockites occur towards the $\mathrm{Ab}$ corner and garnetiferous intermediate charnockites occur towards the Q corner parallel to the $\mathrm{Q}-\mathrm{Ab}$ sideline. The shift of the minima (from intermediate charnockite compositions) toward the Q-Or sideline allows more potassic non-minimum melts (felsic charnockites) to be generated. Further various experimental studies have shown that, with decreasing $a \mathrm{H}_{2} \mathrm{O}$ there is a decrease in $\mathrm{Ab} / \mathrm{Or}$ ratio of the melt (e.g., Holtz et al 1992). The melt compositions become enriched in normative orthoclase at the expense of plagioclase (e.g., Holtz and Johannes 1994). The magnesian intermediate charnockites probably show a close affinity to relatively hydrous, oxidizing magmas, while the ferroan felsic charnockites probably show a close affinity to relatively anhydrous, reduced magmas.

\section{Tectonic scenario}

It is now widely accepted that trace element components of granitoids are a function of the sources and crystallization history of the rock; the tectonic environment is secondary. Hence no traditional trace element discrimination (e.g., $\mathrm{Rb}$ vs. Y+Nb; Pearce et al 1984) was attempted to delineate tectonic environments. Charnockites are likely to have formed in collision settings where substantial crustal thickening occurs (e.g., Zhao et al 1997; Percival and Mortensen 2002; Rajesh 2004b). Many collision zones display associations of calc-alkaline to alkaline magmatism, which are closely related in space and time. Pearce et al (1990) used the composition of volcanic rocks from eastern Anatolia to argue that derivation from the mantle above an earlier subduction gives a calc-alkaline character and derivation from the lithosphere beneath the passive margin gives an alkaline character. In southern India intermediate charnockites generally display a calc-alkaline trend whereas felsic charnockites show a trend of iron-enrichment, comparable to that displayed by alkaline rocks.

In collisional tectonic settings where island arc material has been thrust into deeper levels of the crust or simply accreted from beneath, the formation of tonalite melt and hbl-bearing, opxbearing charnockites is likely. If higher pressures are achieved, garnet will also be a part of these charnockites. In the case of southern India, geochronologic data from the Dharwar craton indicate a major thermal and accretional event close to $2.5 \mathrm{Ga}$, where $3.0-3.4 \mathrm{Ga}$ protoliths (post-accretional) and 2.5-2.6 Ga protoliths (synaccretional) were involved (Jayananda and Peucat 1996). The older non-garnetiferous and garnetiferous charnockites probably represent the accretion of the Madras-Northern-Nilgiri blocks to the Archaean craton in the north. This corresponds to the major thermal and accretional event close to $2.5 \mathrm{Ga}$ (see geologic setting section). In the case of Biligirirangan hill massif, the time gap between crust formation and regional high-grade metamorphism characterizes it as post-accretional (Peucat et al 1989) and probably represents the deeply buried southernmost extension of the Dharwar craton (Pichamuthu 1965). The younger charnockites, covered in this study, from Madurai and Trivandrum blocks are considered in a supercontinent framework and were probably related to the collision between crustal fragments of East and West Gondwana ( 700-650 Ma; Stern 1994), as this event most likely resulted in substantial crustal thickening (Rajesh 2004a). This period is probably characterized by basaltic underplating (Rajesh 2004a), hence the ponding of magmas at the base of the crust, resulting in the formation of anorthosites (e.g., Ashwal et al 1998; Jacobs et al 1998) and/or igneous charnockites (e.g., Kröner et al 2000; Rajesh 2004a, b) at different parts along the Gondwana suture (the continuation of the East African orogen (Stern 1994) into the East Antarctic orogen (Jacobs et al 1998)).

\section{Petrogenesis of charnockites}

\subsection{Nature of the source and petrogenetic process}

The composition of the source plays a critical role in determining the major-element chemistry 
of the melt. Partial melting experiments have shown that granitoid magmas can be produced from a wide range of common rocks at geologically realistic temperatures and pressures, and are characterized by distinct chemical signatures that allow for discrimination between compositionally different protoliths (figure 6). The chemical compositions of the least evolved samples from the southern Indian charnockites seem to be broadly compatible with a basaltic source (figure 6). Ferrodiorite is probably a more likely protolith for the petrogenesis of charnockites by crustal melting than basalt because it has a lower melting point than basalt, and ferro-basalts are found in many extensional settings (Frost and Frost 1997). Scoates et al (1996) showed experimentally that melts of ferrodioritic source compositions are monzonitic. But opx-bearing monzonites (mangerites; Le Maitre et al 2002) have not been found among the southern Indian charnockites considered in this study.

Although all the southern Indian charnockite massifs, considered here, are thought to be of igneous parentage there is an exception in the literature. Condie and Allen (1984) and Peucat et al (1989) suggested an igneous parentage for the Nilgiri charnockites, while Raith et al (1999) indicated a sedimentary parentage for the precursor rocks of the garnetiferous intermediate charnockites of this massif. Raith et al (1999) used major element discrimination (ASI > 1.1; negative values of discriminant factor (DF) of Shaw (1972)) and oxygen isotope data to suggest a sedimentary (psammite and pelite-dominated greywacke-type) provenance for the garnetiferous intermediate charnockites. Although strongly peraluminous (ASI > 1.1) melts, like Nilgiri garnetiferous intermediate charnockites, are commonly taken to have formed from a sedimentary source (Chappell and White 1974), they may also form by melting of biotite-bearing metaluminous felsic rocks (Miller 1985) or even by water-excess melting of mafic rocks (Ellis and Thompson 1986). The use of a different set of geochemical discrimination factors (other than the DF factor) does not rule out the igneous affinity of the source rock of Nilgiri enderbites (figure 7). Further, igneous enclaves present within both garnetiferous and non-garnetiferous enderbites from the Nilgiri hill massif indicates that more mafic magmas and/or other igneous sources may have been involved in the origin of both types of magma.

From a geochemical point of view, metapelites, metagreywackes, felsic orthogneisses and amphibolites all constitute possible sources for the production of peraluminous garnetiferous Nilgiri intermediate charnockites. Melting experiments on pelitic sediments show that they tend to produce
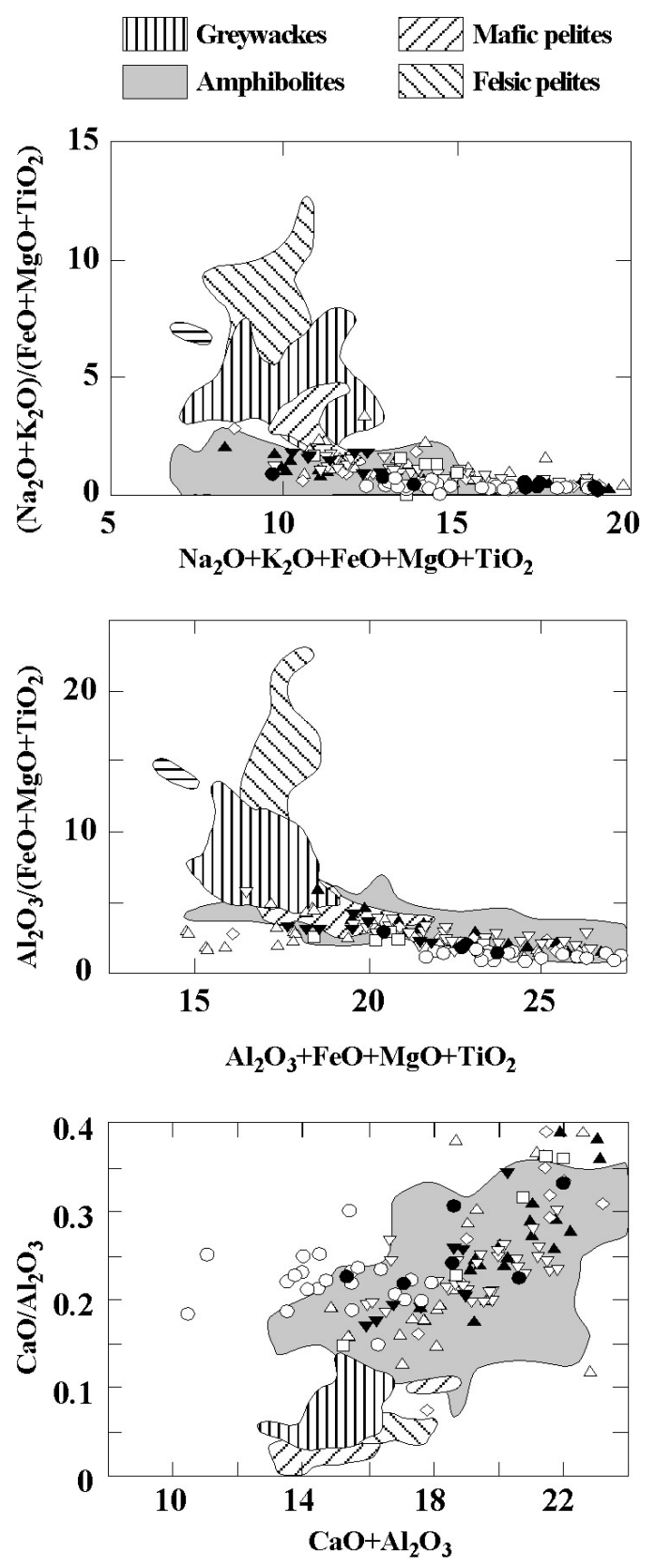

Figure 6. Major element compositions of the southern Indian charnockite samples plotted as a ratio between two variables versus the sum of the same variables. Compositions of melts generated experimentally by dehydration melting of a wide range of bulk compositions are also shown (see Patiño Douce (1999) and Rajesh (1999) for the compilation and sources of data). Same symbology as in figure 5, with non-garnetiferous and garnetiferous intermediate charnockites from Nilgiri hill massif represented by filled and open circle, respectively. All the values are in wt\%.

only small quantities of strongly peraluminous melts with $\mathrm{A} / \mathrm{CNK}>1.3$, and they cannot be suggested as the dominant source for the large volumes of garnetiferous Nilgiri intermediate charnockitic melts with lower A/CNK values $(\sim 1.1-1.28)$. Furthermore, Montel and Vielzeuf (1997) showed that the $\mathrm{K}_{2} \mathrm{O} / \mathrm{Na}_{2} \mathrm{O}$ ratio of melts from a pelitic source 

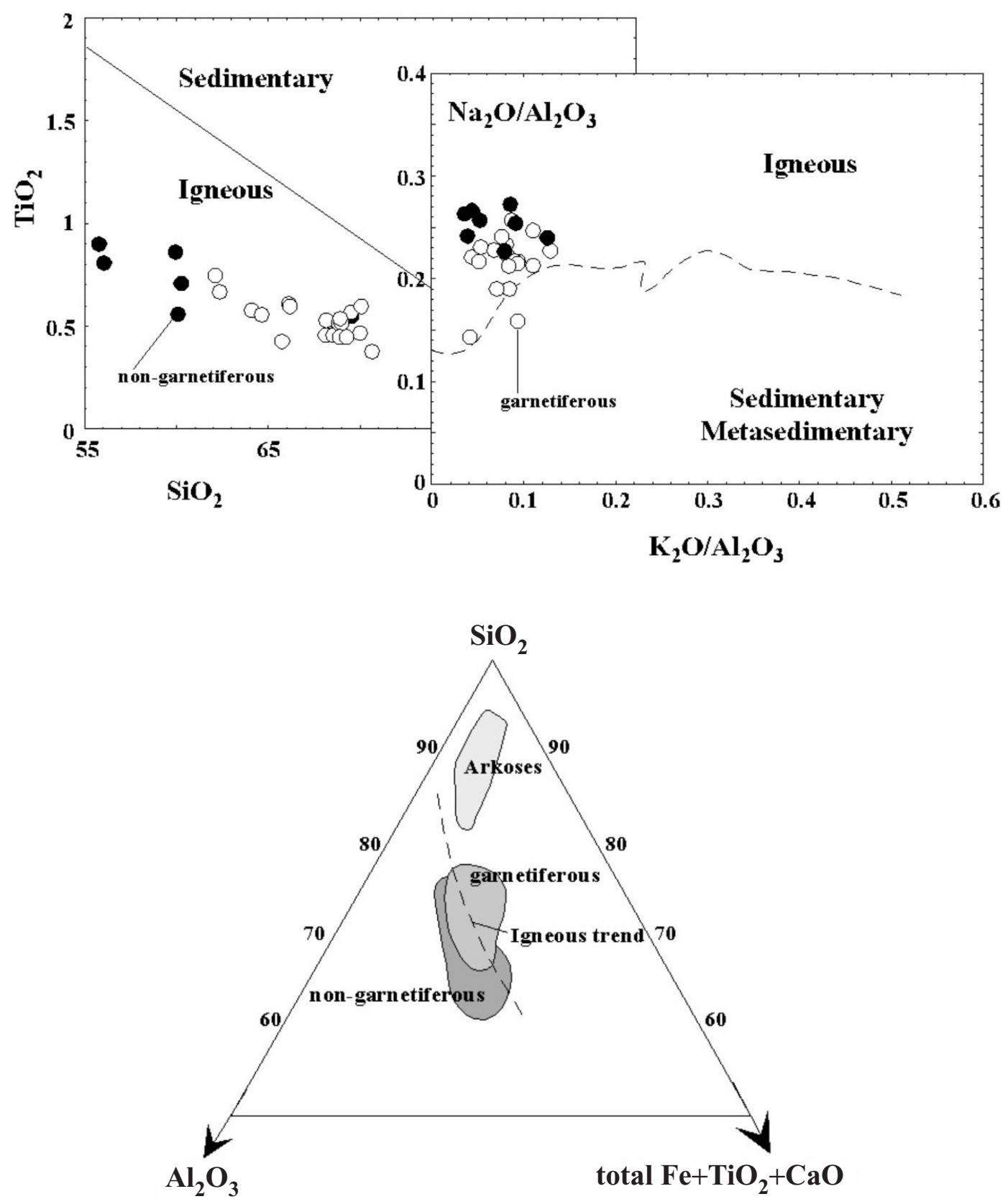

Figure 7. Plots illustrating the igneous affinity of both the non-garnetiferous (filled circle) and garnetiferous (open circle) intermediate charnockites from Nilgiri hill massif. The igneous-sedimentary dividing lines in the $\mathrm{TiO}_{2}-\mathrm{SiO}_{2}$ plot and $\mathrm{Na}_{2} \mathrm{O} / \mathrm{Al}_{2} \mathrm{O}_{3}-\mathrm{K}_{2} \mathrm{O} / \mathrm{Al}_{2} \mathrm{O}_{3}$ plot are from Tarney (1976) and Barrels and MacKenzie (1971). The igneous trend line and the arkose compositional range in the $\mathrm{SiO}_{2}-\mathrm{Al}_{2} \mathrm{O}_{3}-\left(\right.$ total $\left.\mathrm{Fe}+\mathrm{TiO}_{2}+\mathrm{CaO}\right)$ triplot are from Roche (1972).

is significantly higher (average 4-24) than the ratio in the least evolved samples of Nilgiri garnetiferous enderbites $(0.13-0.59$; see figure $4 \mathrm{~b})$. The more feldspar- and quartz-rich metagreywackes and orthogneisses are potentially fertile sources and could give rise to comparatively large volumes of moderately peraluminous melt. In figure 6 , the compositional difference of partial melts produced from sources, such as greywackes, pelites, and amphibolites, can be visualized. It follows from figure 6 that the original melt of the Nilgiri enderbites may be derived from an amphibolitic source.

The similar affinity of the parent rock for the intermediate charnockites from the Biligirirangan hill, Shevroy hill, Nilgiri hill and northern Kerala massifs is substantiated by their similarity to high- $\mathrm{Ba}-\mathrm{Sr}$ granitoids with low $\mathrm{K}_{2} \mathrm{O} / \mathrm{Na}_{2} \mathrm{O}$ ratios (see figure 5) and other elemental characteristics (e.g., high Sr, Ba and LREE, low Y and HREE, elevated $\mathrm{La} / \mathrm{Yb}$ and $\mathrm{Sr} / \mathrm{Y}$ ratios) that are typical of adakites and Archaean TTG (trondhjemite, 
tonalite and granodiorite) suites (e.g., Martin 1986; Drummond and Defant 1990). This character is different from those of felsic charnockites, like those of the Pallavaram massif, which show a similarity to high $\mathrm{Ba}-\mathrm{Sr}$ granitoids with high $\mathrm{K}_{2} \mathrm{O} / \mathrm{Na}_{2} \mathrm{O}$ ratios (see figure 5).

To place additional constraints on the possible source rock(s), total Fe-Na+K-Mg contents of the southern Indian charnockites were compared with some of the available experimental data on compositions of partial melts derived from a variety of crustal rocks (figure 8). Fluid-absent melting of Frich tonalitic gneiss yields strongly peraluminous melts, in contrast to the least evolved samples of the intermediate charnockites. The low normative corundum contents of the intermediate charnockites rule out a pelitic source rock. Although most experimental dehydration melts from metabasaltic sources are strongly peraluminous (Patiño Douce and McCarthy 1998), at very high degrees of partial melting $\left(>1000^{\circ} \mathrm{C}\right)$ dehydration melts produced from metabasaltic sources start to become metaluminous (e.g., Rapp et al 1991). Further their low- $\mathrm{K}_{2} \mathrm{O}$ contents, relatively high contents of $\mathrm{Na}_{2} \mathrm{O}$ and low values of $\mathrm{Mg} \#$, regardless of the degree of partial melting, make metabasaltic rocks suitable source rocks for intermediate charnockites.

Amphibolite dehydration melting experiments conducted at $750-1000^{\circ} \mathrm{C}$ (over a wide variety of pressures) generate granite-granodioritetonalite magmas (e.g., Rushmer 1991; Beard and Lofgren 1991; Patiño Douce and Beard 1995), which are similar to or indistinguishable from charnockite compositions considered in this study. Heat ultimately controls the degree of partial melting, and consequently the residual mineral assemblage. During dehydration melting experiments, hornblende is totally consumed at $925-1000^{\circ} \mathrm{C}$, leaving a granulitic residue of clinopyroxene, orthopyroxene, plagioclase and FeTi oxides with garnet at higher pressures (Rushmer 1991; Beard and Lofgren 1991). Melting to higher temperatures partially consumes the remaining minerals. Although partial melting during the latter stage is volumetrically dominated by plagioclase, the residual mineral assemblage remains unchanged for a considerable isobaric temperature increase.

Beard and Lofgren's (1991) dehydration melting experiments using basaltic and basaltic andesitic starting materials yielded melts similar to southern Indian charnockites (figure 8). Springer and Seck (1997) experiments using basaltic starting material showed that with rising temperatures at constant $\mathrm{CO}_{2}$ content, melts become richer in normative anorthite content similar to the intermediate charnockites from southern India (see fig- ure 3). Kaszuba and Wendlandt (2000) showed that with increased amounts of $\mathrm{CO}_{2}$ at constant temperature, melts become richer in normative orthoclase content similar to the most evolved intermediate charnockite samples (see figure 3). In addition, $\mathrm{CO}_{2}$-rich melt is likely to be enriched in $\mathrm{K}, \mathrm{Ba}$, and $\mathrm{Zr}$ (Eggler 1987), which is characteristic of charnockites like those from southern India (e.g., figure 9; $\mathrm{CO}_{2}$-rich fluid inclusions have been reported from some of the charnockite massifs; e.g., Touret and Hansteen 1988; Srikantappa 1996; Santosh et al 2003; Rajesh 2004a). The lack of $\mathrm{K}$ depletion and extreme $\mathrm{Rb}$ depletion in some of the high pressure Archaean charnockites from southern India may also reflect the presence of a fluid phase with relatively high $\mathrm{CO}_{2} / \mathrm{H}_{2} \mathrm{O}$ ratios (Weaver 1980; Condie and Allen 1984).

In the case of charnockite massifs showing close spatial association (and possibly temporal) of intermediate and felsic varieties (the northern Kerala and Cardamom hill massifs), their near continuous variations in major and trace element compositions probably point to a genetic link between them. If both types of charnockites were differentiated from similar parental magmas, the felsic charnockites would presumably represent a greater degree of fractional crystallization. The lack of systematic $\mathrm{K} / \mathrm{Rb}$ variation, similar levels of incompatible trace elements in both the intermediate and felsic charnockites, and absence or low $\mathrm{Eu}$ anomalies in felsic charnockites do not favor the large amount of fractionation required for the formation of most of these charnockites (e.g., Rajesh 2004a). Constancy of trace element ratios (e.g., $\mathrm{Zr} / \mathrm{Nb}, \mathrm{Ce} / \mathrm{Zr}, \mathrm{Rb} / \mathrm{Zr}$ ) is often cited as evidence that fractional crystallization has been the dominant process in the evolution of particular suites (e.g., Wilson 1989). If trace element ratios are constant within a suite, significant crustal melting and contamination are unlikely to have occurred. In the southern Indian charnockites, however, the above mentioned trace element ratios vary in both intermediate and felsic charnockites. Further bimodality of some of the charnockite suites (with basic member; e.g., Pallavaram massif) can be used to argue against a fractional crystallization model. Fractional crystallization might be responsible for contrasts among intermediate and felsic charnockites of the same massif. This would explain, for example, the decrease in $\left(\mathrm{Eu} / \mathrm{Eu}^{*}\right)_{\mathrm{N}}$ and increase in REE abundances that correlate with increasing $\mathrm{SiO}_{2}$ in some charnockite massifs. Alternatively, such contrasts may reflect differences in the degree of melting with lower degree melts having higher $\mathrm{SiO}_{2}$ and higher REE contents. It is also possible to explain the spatial association of intermediate and felsic charnockites by a two-stage model, which 

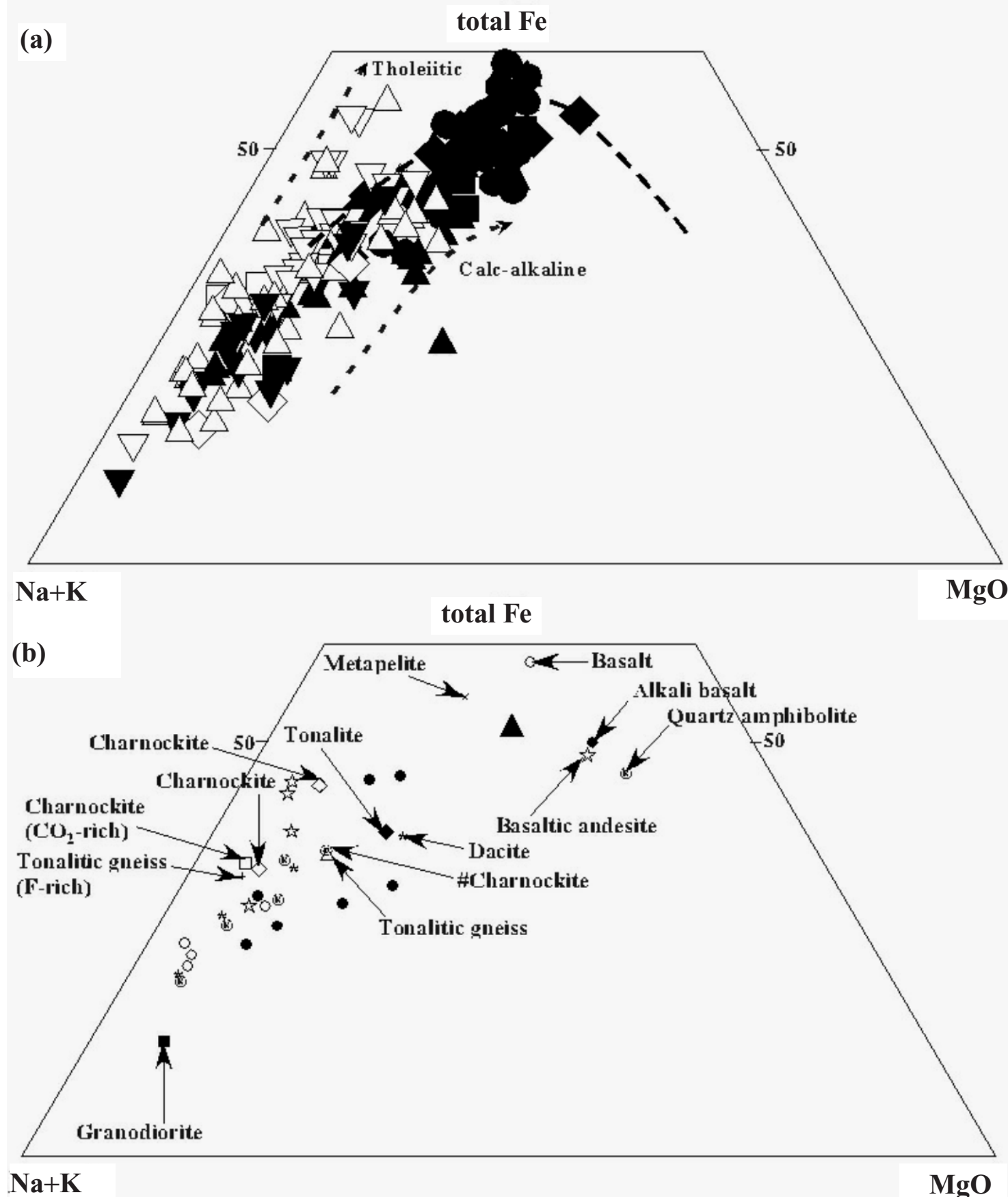

Figure 8. (a) AFM (wt\%) plot of the southern Indian charnockites and (b) experimental data on compositions of partial melts derived from a variety of crustal and mantle rocks by water-under saturated melting. The different rocks and respective experimental P-T conditions are: Dacite $\left(850-950^{\circ} \mathrm{C}, 10 \mathrm{kbar}\right.$; Conrad et al 1988); Basalt (850-950 ${ }^{\circ} \mathrm{C}, 3-6.9 \mathrm{kbar}$; Beard and Lofgren 1991); Basaltic andesite $\left(900-1000^{\circ} \mathrm{C}, 3-6.9 \mathrm{kbar}\right.$; Beard and Lofgren 1991); Tonalitic gneiss $\left(875-1050^{\circ} \mathrm{C}, 10 \mathrm{kbar}\right.$; Skjerlie et al 1993); Metapelite $\left(900-950^{\circ} \mathrm{C}, 10 \mathrm{~kb}\right.$; Skjerlie et al 1993); Tonalitic gneiss (F-rich) $\left(900-1075^{\circ} \mathrm{C}\right.$, 6-10 kbar; Skjerlie and Johnston 1993); Charnockite $\left(850-950^{\circ} \mathrm{C}, 6.9 \mathrm{kbar}\right.$; Beard et al 1994); Charnockite $\left(\mathrm{CO}_{2}\right.$-rich $)\left(950^{\circ} \mathrm{C}, 6.9 \mathrm{kbar}\right.$; Beard et al 1994); Quartz amphibolite $\left(900-1000^{\circ} \mathrm{C}, 5-10 \mathrm{~kb}\right.$; Patiño Douce and Beard 1995); Tonalite (950 ${ }^{\circ} \mathrm{C}$, 4-8 kbar; Patiño Douce 1997); Granodiorite (950 ${ }^{\circ} \mathrm{C}$, 4-8 kbar; Patiño Douce 1997); \#Charnockite (950-1150 ${ }^{\circ} \mathrm{C}, 15 \mathrm{kbar}$; Litvinovsky et al 2000); Alkali basalt (1000-1025 C, $7 \mathrm{kbar}$; Kaszuba and Wendlandt 2000). The respective compositions of the starting material (indicated by arrow) and the product(s) of water-under saturated melting of some of these rocks are shown (by similar symbols). For figure 8 (a) same symbology as in figure 4.

assumes an initial low degree of partial melting and subsequent fractionation. The possibility of fractional rather than batch melting for the for- mation of those charnockite massifs having REE patterns with a slight positive Eu anomaly cannot be discounted. 


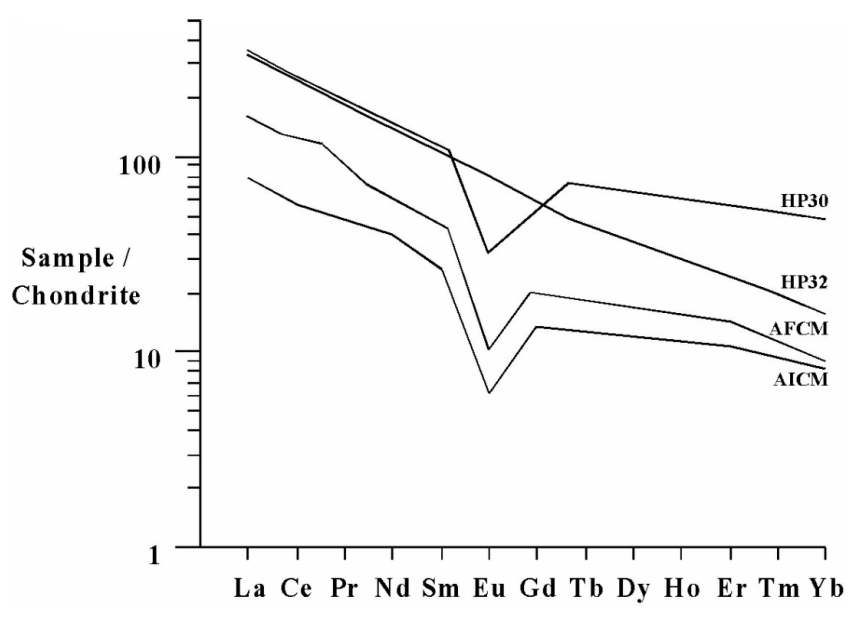

Figure 9. Chondrite-normalized REE patterns showing the similarity of the average felsic (AFCM) and intermediate (AICM) charnockite samples from the Cardamom hill massif (Chacko et al 1992) to $\mathrm{CO}_{2}$-rich charnockite sample (HP30) used in Beard et al (1994) experiments. HP32 is a charnockite sample used in the Beard et al experiments.

\subsection{The influence of temperature and water fugacity}

Regarding the charnockite massifs, which show a spatial association of intermediate and felsic charnockites, different experimental studies have shown that different melts embracing the variation range of the particular charnockite massif can be generated from a single source material under different conditions (e.g., temperature, water fugacity). As far as temperature is concerned, for e.g., $10 \mathrm{kbar}$ experimental data of Conrad et al (1988) show the possibility of generating both metaluminous partial melts and peraluminous melts from the same dacitic source material. The former, obtained at low $a \mathrm{H}_{2} \mathrm{O}(0.50-$ $0.25)$, high temperatures $\left(900-975^{\circ} \mathrm{C}\right)$, and high melt proportions $(>75 \%$ ), would be in equilibrium with restitic cpx+opx+plg. At similar $a \mathrm{H}_{2} \mathrm{O}$ and slightly lower temperatures $\left(825-875^{\circ} \mathrm{C}\right)$ peraluminous melts are obtained that would be in equilibrium with $\mathrm{cpx}+\mathrm{opx}+\mathrm{plg} \pm \mathrm{qtz}$. Although a close similarity exists between the two melting residues obtained, the different phase proportions may account for the different chemical compositions found in the parental melts in the two-granitoid sequences. Data from the melting experiments of Beard and Lofgren (1991) also support production of intermediate magmas at $950-1000^{\circ} \mathrm{C}$, and felsic magmas at $850-950^{\circ} \mathrm{C}$. However, fluid-absent melting of slightly metaluminous, metavolcaniclastic rocks at $10 \mathrm{kbar}$ yields high-K tonalitic and/or granodioritic melts at $1050^{\circ} \mathrm{C}$ and high-K peraluminous granitic rocks at about $975^{\circ} \mathrm{C}$ (Skjerlie and Johnston 1996).
Experimental studies have shown that water fugacity strongly influences melt composition and residuum mineralogy during partial melting of basaltic compositions at mid- to lower-crustal pressures (e.g., Holloway and Burnham 1972; Beard and Lofgren 1991). The main effect of increased $f_{\mathrm{H}_{2} \mathrm{O}}$ during melting is to increase the amount of amphibole and decrease the amount of plagioclase in the residuum. Depending on the bulk composition, dehydration melting of amphibolite yields $6-60 \%$ melt at $900-1000^{\circ} \mathrm{C}$, while vapor-saturated melting yields similar amounts of melt at slightly lower temperatures, $800-950^{\circ} \mathrm{C}$ (Beard and Lofgren 1991; Rushmer 1991). Further liquids produced by dehydration melting are tonalitic and coexist with a residuum dominated by plagioclase, pyroxene, and Fe-Ti oxides (Beard and Lofgren 1991; Rushmer 1991). In contrast, melts generated in the presence of an $\mathrm{H}_{2} \mathrm{O}$-rich vapor phase are high in silica and alumina, low in magnesium, and coexist with a residuum of amphibole, clinopyroxene, Fe-Ti oxides and minor plagioclase (Beard and Lofgren 1991).

It follows from these experimental data that the intermediate and felsic charnockites can be derived from similar basaltic sources, with the intermediate charnockites originating by dehydration melting and the felsic ones by melting under higher $f_{\mathrm{H}_{2} \mathrm{O}}$. This does not require that the felsic charnockites crystallized from water-saturated magmas, because as recognized by Helz (1976) and others, melt composition in this case is dependent primarily upon $P_{\mathrm{H}_{2} \mathrm{O}}$ rather than $P_{\text {total }}$. The compositional similarity between intermediate charnockites and the experimental glasses produced by $20-50 \%$ melting of basaltic source rocks at $900-1000^{\circ} \mathrm{C}$ and low $P_{\mathrm{H}_{2} \mathrm{O}}$ supports dehydration melting (figure 10). Felsic charnockites, when compared with intermediate charnockites at equal $\mathrm{SiO}_{2}$, are higher in $\mathrm{Al}_{2} \mathrm{O}_{3}$ and lower in $\mathrm{MgO}$. Similar trends are observed with increased $f_{\mathrm{H}_{2} \mathrm{O}}$ among the experimental glasses (Beard and Lofgren 1991). Generation of felsic charnockites at higher $f_{\mathrm{H}_{2} \mathrm{O}}$ is also suggested by their closer resemblance to glasses formed at $1 \mathrm{kbar} P_{\mathrm{H}_{2} \mathrm{O}}$ than to those formed by dehydration melting (figure 10). Thus dehydration and vapour-saturated melting of basaltic rocks is a possible primary mechanism in the formation of southern Indian charnockite massifs.

\subsection{A plausible model}

A possible model is suggested for the formation of intermediate and felsic charnockites from southern India, as an extension of the one proposed by Rajesh (2004b). It is argued that their sources were roughly similar, and that the change from calc-alkaline (magnesian) to alkaline (ferroan) 


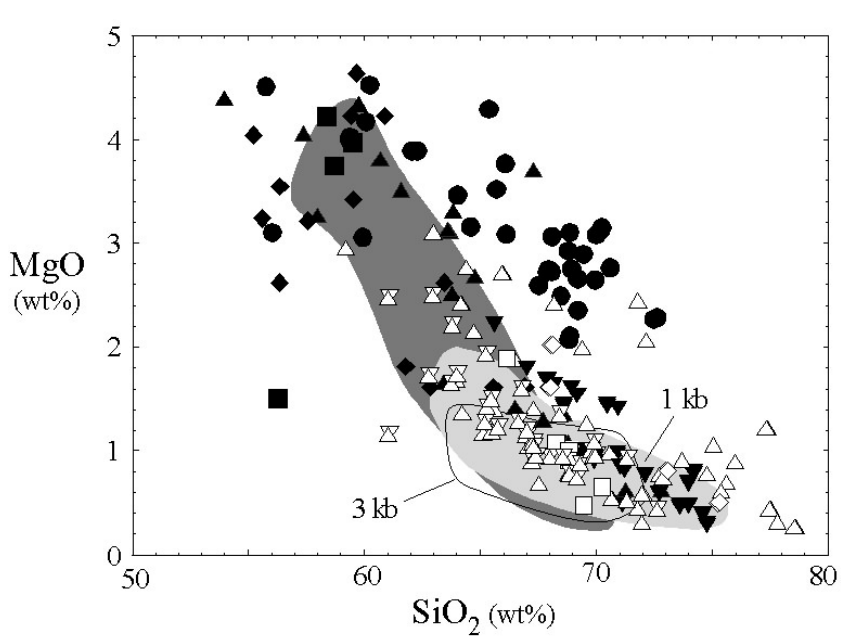

Figure 10. $\mathrm{MgO}$ vs. $\mathrm{SiO}_{2}$ plot illustrating the comparison of southern Indian charnockite compositions with glasses produced by melting of greenstone and amphibolite at different $f_{\mathrm{H}_{2} \mathrm{O}}$. Glass analyses (dehydration melting (darker field) at 950-1000 ${ }^{\circ}$; water-saturated melting (lighter field) at 1 and $\left.3 \mathrm{~kb} P_{\text {total }}\right)$ are from Beard and Lofgren (1991), Rushmer (1991), and Wolf and Wyllie (1989). Same symbology as in figure 4 .

charnockitic magmatism was caused by increasing water contents. Rajesh (2004b) suggested that the southern Indian charnockites were produced by partial melting of amphibole-bearing mafic lower crust that formed by underplating of basaltic magmas. Here the crust probably would have acted as a barrier to basaltic magmas ascending from the mantle, causing them to pond and crystallize, and leading to the development of a zone of lower crustal melt generation. Melting of this lower crust already close to or slightly below its solidus, forming charnockites, was probably driven by the intrusion of mantle-derived basaltic magmas. Importantly variations in the water contents of these basalts exert a strong influence on the resulting charnockitic melt compositions. Intrusion of relatively anhydrous basalts resulted in dehydration melting of the lower crust and production of intermediate charnockites (trondhjemites to tonalites). In contrast, intrusion of hydrous basalts resulted in production of felsic charnockites (granodiorites to granites).

This model outlines a chemical as well as physical role for basalts in the production of charnockites, and implies that a thick lower crust is a requirement for large-scale generation of charnockites. It attributes much of the lithologic diversity within some charnockite massifs (intermediate to felsic) to differences in melting reactions. The model does not preclude the possibility that crystal fractionation, assimilation, and/or mixing may have modified individual magma batches, but such processes may be of secondary importance in determining the general lithology of charnockite massifs. In the case of spatially associated charnockite massifs, the possibility of an initial low degree of partial melting and subsequent fractional crystallization for their petrogenesis is not excluded.

The suggested two-stage model relates the generation of older charnockite massifs to the dynamic underplating of the southern Indian crust during late Archaean to early Proterozoic time. During the first stage partial melting of slightly enriched upper mantle creates a mafic underplate. In the second stage this newly accreted material is itself partially melted, giving rise to the non-garnetiferous intermediate charnockites, and subsequently after the underplate has thickened through the garnet-in transition, the more voluminous garnetiferous felsic charnockites were formed. The younger charnockite massifs were probably related to the collision between crustal fragments of East and West Gondwana, as this event most likely resulted in substantial crustal thickening.

\section{Conclusions}

- Among the charnockite massifs from southern India, the older Biligirirangan hill, Shevroy hill and Nilgiri hill massifs are intermediate charnockites, with the Pallavaram massif consisting dominantly of felsic charnockites. The charnockite massifs of northern Kerala and Cardamom hill show a spatial association of intermediate and felsic charnockites, with the youngest Nagercoil massif consisting of felsic charnockites.

- The southern Indian charnockite massifs show a similarity to high-Ba-Sr granitoids, with intermediate charnockites showing a similarity to high- $\mathrm{Ba}-\mathrm{Sr}$ granitoids with low $\mathrm{K}_{2} \mathrm{O} / \mathrm{Na}_{2} \mathrm{O}$ ratios, while felsic charnockites show a similarity to high-Ba-Sr granitoids with high $\mathrm{K}_{2} \mathrm{O} / \mathrm{Na}_{2} \mathrm{O}$ ratios.

- A two-stage model is proposed here for the formation of southern Indian charnockites. The first stage involved a period of basalt underplating, with the ponding of alkaline mafic magmas. Partial melting of this mafic lower crust formed the charnockitic magmas. Emplacement of basalt with low water content would lead to dehydration melting of the lower crust forming intermediate charnockites. Conversely, emplacement of hydrous basalt would result in melting at higher $f_{\mathrm{H}_{2} \mathrm{O}}$ favoring production of more siliceous felsic charnockites.

- It is inferred that the southern Indian crust was affected by at least two crustal thickening 
phases, one during late Archaean to early Proterozoic and one during late Proterozoic. The first one was related to the accretion of the older crustal blocks (Madras-Northern-Nilgiri blocks) with the Archaean craton to the north. The second crustal thickening stage occurred in a supercontinent formation process, probably during the collision between crustal fragments of East and West Gondwana along the Gondwana suture.

\section{Acknowledgements}

The first author acknowledges the support and discussions with Natsumi Takao. RHM thanks University of Queensland and MS thanks Kochi University for facilities. We thank the three anonymous referees for their comments and criticisms. Two of them failed to comprehend our views on the possible igneous parentage of the charnockite massifs, although we hope that they will adopt a broader scientific view considering the global debate surrounding this interesting theme. The third reviewer provided very constructive and encouraging comments. Editorial comments by Hetu Sheth were valuable. This is a contribution to the Gondwana Institute for Geology and Environment (GIGE) and IGCP 453.

\section{References}

Andersen D J, Lindsley D H and Davidson P M 1993 QUILF: a Pascal program to assess the equilibria among $\mathrm{Fe}-\mathrm{Mg}-\mathrm{Mn}-\mathrm{Ti}$ oxides, pyroxenes, olivine, and quartz; Comp. Geosci. 19 1333-1350

Ashwal L D, Hamilton M A, Morel V P I and Rambeloson R A 1998 Geology petrology and isotope geochemistry of massif-type anorthosites from southwest Madagascar; Contrib. Mineral. Petrol. 133 389-401

Barrels R M and Mackenzie F T 1971 Evolution of sedimentary rocks (New York: WW Norton and Comp. Inc.)

Bartlett J M, Harris N B W, Hawkesworth C J and Santosh M 1995 New isotope constraints on the crustal evolution of South India and Pan-African granulite metamorphism; Geol. Soc. India Mem. 34 391-397

Bartlett J M, Page D J S, Harris N B W, Hawkesworth C J and Santosh M 1998 The application of single zircon evaporation and model $\mathrm{Nd}$ ages to the interpretation of polymetamorphic terrains: an example from the Proterozoic mobile belt of South India; Contrib. Mineral. Petrol. 131 181-195

Beard J S and Lofgren G E 1991 Dehydration melting and water-saturated melting of basaltic and andesitic greenstones and amphibolites at 1,3 and $6.9 \mathrm{~kb} ;$ J. Petrol. 32 365-401

Beard J S, Lofgren G E, Sinha A K and Tollo R P 1994 Partial melting of apatite-bearing charnockite granulite and diorite: melt compositions restite mineralogy and petrologic implications; J. Geophys. Res. 99 21591-21603
Bhattacharya A and Sen S K 1986 Granulite metamorphism, fluid buffering, and dehydration melting in the Madras charnockites and metapelites; J. Petrol. 27 1119-1141

Bhattacharya S and Sen S K 2002 Discussion of the origin of 'arrested' charnockitisation in the Chilka Lake area, Eastern Ghats Belt, India; Geol. Mag. 139 361-364

Bohlender F, van Reenen D D and Barton Jr J M 1992 Evidence for metamorphic and igneous charnockites in the southern Marginal zone of the Limpopo Belt; Precamb. Res. 55 429-449

Brandon A D and Meen J K 1995 Nd isotopic evidence for the position of southernmost Indian terranes within East Gondwana; Precamb. Res. 70 269-280

Braun I, Montel J-M and Nicollet C 1998 Electron microprobe dating of monazites from high-grade gneisses and pegmatites of the Kerala khondalite belt, southern India; Chem. Geol. 146 65-85

Bryant C J, Arculus R J and Chappell B W 1997 Clarence river supersuite: $250 \mathrm{Ma}$ Cordilleran tonalitic I-type intrusions in eastern Australia; J. Petrol. 38 975-1001

Cenki B, Kriegsman L M and Braun I 2002 Melt-producing and meltconsuming reactions in the Achankovil cordierite gneisses, South India; J. Meta. Geol. 20 543-561

Chacko T, Kumar G R R and Newton R C 1987 Metamorphic P-T conditions of the Kerala (South India) Khondalite Belt a granulite-facies supracrustal terrain; J. Geol. 95 343-358

Chacko T, Kumar G R R, Meen J K and Rogers J J W 1992 Geochemistry of high grade supracrustal rocks from the Kerala Khondalite Belt and adjacent massif charnockites; Precamb. Res. 55 469-489

Chacko T, Lamb M and Farquhar J 1996 Ultra-high temperature metamorphism in the Kerala Khondalite Belt; Gond. Res. Group Mem. 3 157-165

Chappell B W and White A J R 1974 Two contrasting granite types; Pacific Geol. 8 173-174

Choudhary A K, Harris N B W, van Calsteren P and Hawkesworth C J 1992 Pan-African charnockite formation in Kerala, South India; Geol. Mag. 129 $257-264$

Collins W J 1996 S- and I-type granitoids of the eastern Lachlan fold belt granitoids: products of three-component mixing; Trans. R. Soc. Edinburgh 88 171-179

Collins W J, Beams S D, White A J R and Chappell B W 1982 Nature and origin of A-type granites with particular reference to southeastern Australia; Contrib. Mineral. Petrol. 80 189-200

Condie K C and Allen P 1984 Origin of Archaean charnockites from southern India; In: Archaean Geochemistry (eds) A Kröner, G N Hanson and A M Goodwin (Berlin: Springer) 183-203

Condie K C, Allen P and Narayana B L 1982 Geochemistry of the Archaean low- to high-grade transition zone, southern India; Contrib. Mineral. Petrol. 81 157167

Conrad W K, Nicholls I A and Wall V J 1988 Watersaturated and -undersaturated melting of metaluminous and peraluminous crustal compositions at $10 \mathrm{~kb}$ : evidence for the origin of silicic magmas in the Taupo volcanic zone New Zealand and other occurrences; J. Petrol. 29 765-803

Crawford A R 1969 India, Ceylon and Pakistan new age data and comparison; Nature 223 380-384

Debon F and Le Fort P 1988 A cationic classification of common plutonic rocks and their magmatis associations: principles, method, applications; Bull. Minéral. 111 $493-510$ 
Dobmeier C and Raith M M 2000 On the origin of 'arrested' charnockitization in the Chilka Lake area, Eastern Ghats Belt, India: a reappraisal; Geol. Mag. 137 27-37

Drummond M S and Defant M J 1990 A model for trondhjemite-tonalite-dacite genesis and crustal growth via slab melting: Archean to modern comparisons; J. Geophys. Res. 95 21503-21521

Duchesne J-C and Wilmart E 1997 Igneous charnockites and related rocks from the Bjerkreim-Sokndal layered intrusion (southwest Norway): a jotunite (hypersthene monzodiorite)-derived A-type granitoid suite; J. Petrol. 38 337-369

Eggler D H 1987 Solubility of major and trace elements in mantle metasomatic fluids: experimental constraints; In: Mantle metasomatism (eds) M A Menzies and C J Hawkesworth (London: Academic Press) $21-41$

Ellis D J and Thompson A B 1986 Subsolidus and partial melting reactions in the quartz-excess $\mathrm{CaO}+\mathrm{MgO}+$ $\mathrm{Al}_{2} \mathrm{O}_{3}+\mathrm{SiO}_{2}+\mathrm{H}_{2} \mathrm{O}$ system under water-excess and waterdeficient conditions to $10 \mathrm{~kb}$ : some implications for the origin of peraluminous melts from mafic rocks; J. Petrol. 27 91-121

Fowler M B and Henney P J 1996 Mixed Caledonian appinite magmas: implications for lamprophyre fractionation and high Ba-Sr granite genesis; Contrib. Miner. Petrol. 126 199-215

Fowler M B, Henney P J, Darbyshire D P F and Greenwood P B 2001 Petrogenesis of high Ba-Sr granites: the Rogart pluton, Sutherland; J. Geol. Soc. London 158 521-534

Friend C R L 1981 The timing of charnockite and granite formation in relation to influx of $\mathrm{CO}_{2}$ at Kabbaldurga, Karnataka, South India; Nature 294 550-552

Frost B R, Barnes C G, Collins W J, Arculus R J, Ellis D J and Frost C D 2001 A geochemical classification for granitic rocks; J. Petrol. 42 2033-2048

Frost C D and Frost B R 1997 Reduced rapakivi-type granite: the tholeiitic connection; Geology 25 647-650

Frost C D, Frost B R, Chamberlain K R and Edwards B R 1999 Petrogenesis of the 1.43 Ga Sherman batholith, SE Wyoming, USA: a reduced rapakivi-type anorogenic granite; J. Petrol. 40 1771-1802

Green T H and Pearson N J 1986 Ti-rich accessory phase saturation in hydrous mafic-felsic compositions at high $\mathrm{P}$, T; Chem. Geol. 54 185-201

Griffiths B J, Jahn B-M and Sen S K 1987 Sm-Nd isotopes and REE geochemistry of Madras granulites, India: an introductory statement; Precamb. Res. 37 343-355

Hansen E C, Janardhan A S, Newton R C, Prame W K B N and Kumar G R R 1987 Arrested charnockite formation at Kabbaldurga, South India; Nature 278 511-514

Harley S L and Santosh M 1995 Wollastonite at Nuliyam, Kerala, South India: a reassessment of $\mathrm{CO}_{2}$ infiltration and charnockite formation at a classic locality; Contrib. Mineral. Petrol. 120 83-94

Harris N B W, Holt R W and Drury S A 1982 Geobarometry, geothermometry, and late Archean geotherms from granulite facies terrain of South India; J. Geol. 90 509-527

Harris N B W, Santosh M and Taylor P N 1994 Crustal evolution in South India: constraints from Nd isotopes; J. Geol. 102 139-150

Helz R T 1976 Phase relations of basalts in their melting ranges at $P_{\mathrm{H}_{2} \mathrm{O}}=5 \mathrm{kbar}$, part II: melt compositions; J. Petrol. 17 139-193

Holland T H 1900 The charnockite series, a group of Archaean hypersthenic rocks in Peninsular India; Mem. Geol. Surv. India 28 192-249
Holloway J R and Burnham C W 1972 Melting relations of basalt with equilibrium water pressure less than total pressure; J. Petrol. 13 1-29

Holtz F and Johannes W 1994 Maximum and minimum water contents of granitic melts: implications for chemical and physical properties of ascending magmas; Lithos 32 149-159

Holtz F, Pichavant M, Barbey P and Johannes W 1992 Effect of $\mathrm{H}_{2} \mathrm{O}$ on liquidus phase relations in the haplogranite system at 2 and $5 \mathrm{kbar} ; \mathrm{Am}$. Mineral. $\mathbf{7 7}$ 1223-1241

Howie R A 1955 The geochemistry of the charnockite series of Madras, India; Trans. R. Soc. Edinburgh Earth Sci. 62 $725-768$

Howie R A and Subramaniam A P 1957 The paragenesis of garnet in charnockite, enderbite, and related granulites; Mineral. Mag. 31 565-586

Jackson D H, Mattey D and Harris N B W 1988 Carbon isotopic compositions of fluid inclusions in charnockites from southern India; Nature 333 167-170

Jacobs J, Fanning C M, Henjes-Kunst F, Olesch M and Paech H-J 1998 Continuation of the Mozambique belt into East Antarctica: Grenville-age metamorphism and polyphase Pan-African high-grade events in central Dronning Maud Land; J. Geol. 106 385-406

Janardhan A S, Jayananda M, and Shankara M A 1994 Formation and tectonic evolution of granulites from the Biligirirangan and Nilgiri hills, S. India: geochemical and isotopic constraints; J. Geol. Soc. India $4427-40$

Janardhan A S, Newton R C and Hansen E C 1982 The transformation of amphibolite facies gneiss to charnockite in southern Karnataka and northern Tamil Nadu, India; Contrib. Mineral. Petrol. 79 130-149

Jayananda M and Peucat J J 1996 Geochronological framework of southern India; Gond. Res. Group Mem. 3 53-75

Jayananda M, Janardhan A S, Sivasubramanian P and Peucat J-J 1995 Geochronologic and isotopic constraints on the granulite formation in the Kodaikanal area, southern India; Geol. Soc. India Mem. 34 373-390

Kaszuba J P and Wendlandt R F 2000 Effect of carbon dioxide on dehydration melting reactions and melt compositions in the lower crust and the origin of alkaline rocks; J. Petrol. 41 363-386

Kilpatrick J A and Ellis D J 1992 C-type magmas: igneous charnockites and their extrusive equivalents; Trans. $R$. Soc. Edinburgh Earth Sci. 83 155-164

Kröner A, Hegner E, Collins A S, Windley B F, Brewer T S, Razakamanana T and Pidgeon R T 2000 Age and magmatic history of the Antananarivo Block central Madagascar as derived from zircon geochronology and $\mathrm{Nd}$ isotopic systematics; Am. J. Sci. 300 251-288

Kumar V N and Harley S L 2000 A reappraisal of the pressure-temperature path of granulites from the Kerala Khondalite Belt, southern India; J. Geol. 108 687-703

Le Maitre R W (ed) 2002 Igneous rocks: A classification and glossary of terms (Cambridge Univ. Press)

Litvinovsky B A, Steele I M and Wickham S M 2000 Silicic magma formation in overthickened crust: Melting of charnockite and leucogranite at 15,20 and $25 \mathrm{kbar}$; J. Petrol. 41 717-737

Mahabaleswar B, Jayananda M, Peucat J J and Swamy S N 1995 Archean high grade gneiss complex from SatnurHalagur-Sivasamudram areas, Karnataka, South India; J. Geol. Soc. India 45 33-49

Martin H 1986 Effect of steeper Archaean geothermal gradient on geochemistry of subduction-zone magmas; Geology $14753-756$

Miller C F 1985 Are strongly peraluminous magmas derived from pelitic sedimentary sources?; J. Geol. 93 673-689 
Miller J S, Santosh M, Pressley R A, Clemens A S and Rogers J J W 1996 A Pan-African thermal event in southern India; J. Southeast Asi. Earth Sci. 14 127-136

Mohan A and Jayananda M 1999 Metamorphism and isotopic evolution of granulites of southern India: reference to Neoproterozoic crustal evolution; Gond. Res. 2 251-262

Mohan A and Windley B 1993 Crustal trajectory of sapphirine-bearing granulites from Ganguvarpatti, South India: evidence for isothermal decompression path; J. Met. Geol. 11 867-878

Mojzsis S J, Devaraju T C and Newton R C 2003 Ion Microprobe U-Pb Age Determinations on Zircon from the Late Archean Granulite Facies Transition Zone of Southern India; J. Geol. 111 407-425

Montel J M and Vielzeuf D 1997 Partial melting of metagreywackes, Part II. Compositions of minerals and melts; Contrib. Mineral. Petrol. 128 176-196

Naha K, Srinivasan R and Jayaram S 1993 Structural relations of charnockites of the Archean Dharwar craton, southern India; J. Meta. Geol. 11 889-895

Nambiar C G, Bhaskar Rao B, Parthasarathy R and Fedkin V V 1992 Geochemistry and genesis of charnockites and associated gneisses from northern Kerala, India; In: In high-grade metamorphics (ed) A Barto. Theophrastus Pub, Athens 187-215

Newton R C, Smith J V and Windley B F 1980 Carbonic metamorphism granulites and crustal growth; Nature $\mathbf{2 8 8}$ 45-50

Patiño Douce A E 1997 Generation of metaluminous A-type granites by low-pressure melting of calc-alkaline granitoids; Geology 25 743-746

Patiño Douce A E 1999 What do experiments tell us about the relative contributions of crust and mantle to the origin of granitic magmas?; Geol. Soc. Sp. Pub. 168 55-75

Patiño Douce A E and Beard J S 1995 Dehydration melting of biotite gneiss and quartz amphibolite from 3 to $15 \mathrm{kbar}$; J. Petrol. 36 707-738

Patiño Douce A E and McCarthy T C 1998 Melting of crustal rocks during continental collision and subduction; In: When continents collide: Geodynamics and geochemistry of ultrahigh pressure rocks (eds) B R Hacker and J G Liou (Dordrecht: Kluwer Academic Press) 27-55

Pearce J A, Bender J F, De Long S E, Kidd W S F, Low P J, Guner Y, Saroglu F, Yilmaz Y, Moorbath S and Mitchell J G 1990 Genesis of collision volcanism in Eastern Anatolia, Turkey; J. Volcan. Geotherm. Res. 44 189-229

Pearce J A, Harris N B W and Tuttle A C 1984 Trace element discrimination diagrams for the tectonic interpretation of igneous rocks; J. Petrol. 25 956-983

Percival J A and Mortensen J K 2002 Water-deficient calc-alkaline plutonic rocks of northeastern Superior Province, Canada: significance of charnockitic magmatism; J. Petrol. 43 1617-1650

Peucat J J, Mahabaleswar B and Jayananda M 1993 Age of younger tonalitic magmatism and granulite metamorphism in the South Indian transition zone (Krishnagiri area): comparison with older Precambrian gneisses from Hassan-Gorur area; J. Meta. Geol. 11 879-888

Peucat J J, Vidal P, Griffiths B J and Condie K C 1989 Sr, $\mathrm{Nd}$ and $\mathrm{Pb}$ isotopic systems in the Archaean low- to highgrade transition zone of southern India: syn-accretion vs. post-accretion granulites; J. Geol. 97 537-550

Pichamuthu C S 1960 Charnockite in the making; Nature 188 135-136

Pichamuthu C S 1965 Regional metamorphism and charnockitization in Mysore state, India; Ind. Mineral. 6 $119-126$
Raith M and Srikantappa C 1993 Arrested charnockite formation at Kottavattom, southern India; J. Meta. Geol. 11 815-832

Raith M, Karmakar S and Brown M 1997 Ultrahigh temperature metamorphism and multistage decompressional evolution of sapphirine granulites from the Palni Hill ranges, South India; J. Met. Geol. 15 379-399

Raith M, Srikantappa C, Ashamanjari K G and Spiering B 1990 The granulite terrane of the Nilgiri hills (southern India): characterization of high-grade metamorphism; In: Granulites and crustal evolution (eds) D Vielzeuf and $\mathrm{Ph}$ Vidal. NATO ASI series C 311 (Dordrecht: Kluwer Academic Publishers) 339-365

Raith M, Srikantappa C, Buhl D and Kühler H 1999 The Nilgiri Enderbites, South India: nature and age constraints on protolith formation, high-grade metamorphism and cooling history; Precamb. Res. 98 129-150

Rajesh H M 1999 Characterization and origin of alkaline and calc-alkaline aluminous A-type granitoids from southwestern India: implications for Gondwanaland tectonics; Unpublished DSc thesis Osaka City University, Japan $317 \mathrm{p}$

Rajesh H M 2000 Characterization and origin of a compositionally zoned aluminous A-type granite from South India; Geol. Mag. 137 291-318

Rajesh H M 2003 Outcrop-scale silicate liquid immiscibility from an alkali syenite (A-type granitoid)-pyroxenite association near Puttetti, Trivandrum Block, South India; Contrib. Mineral. Petrol. 145 612-627

Rajesh H M 2004a The igneous charnockite - high-K alkalicalcic I-type granite - incipient charnockite association in Trivandrum Block, southern India; Contrib. Mineral. Petrol. 147 346-362

Rajesh H M 2004b Charnockite - calc-alkaline granite and Charnockite - alkali granite link in high-grade terrains: examples from southwestern India; (under revision)

Rajesh H M 2004c Progressive or continual exsolution in pyroxenes: an inidcator of polybaric igneous crystallization for the Perinthatta anorthositic gabbro, northern Kerala, southwestern India; J. Asian Earth Sci. (in press)

Rajesh H M, Santosh M and Yoshida M 1996 The felsic magmatic province in East Gondwana: implications for Pan-African tectonics; J. Southeast Asi. Earth Sci. 14 275-291

Rao R D, Charan S N and Natarajan R 1991 P-T conditions and geothermal gradients of gneiss-enderbitic rocks: Dharmapuri area, Tamil Nadu, India; J. Petrol. 32 539-554

Rapp R P, Watson E B and Miller C F 1991 Partial melting of amphibolite/eclogites and the origin of Archean trondhjemites and tonalites; Precamb. Res. 51 1-25

Roche de La H 1972 Geochemical characterization of the metamorphic domains: survival and testimony of the premetamorphic history; Sci. Terre. 19 103-117

Rushmer T 1991 Partial melting of two amphibolites: contrasting experiment results under fluid absent conditions; Contrib. Mineral. Petrol. 107 41-59

Santosh M, Harris N B W, Jackson D H and Mattey D P 1990 Dehydration and incipient charnockite formation: a phase equilibria and fluid inclusion study from southern India; J. Geol. 98 915-926

Santosh M, Tagawa M, Taguchi S and Yoshikura S 2003 The Nagercoil Granulite Block, southern India: petrology, fluid inclusions and exhumation history; J. Asian Earth Sci. 22 131-155

Santosh M, Tagawa M, Taguchi S and Yoshikura S 2004 Geochemical characterization of various rock units within the Nagercoil Granulite Block, southern India; (submitted) 
SatishKumar M, Wada H and Santosh M 2002 Constraints on the application of carbon isotope thermometry in highto ultrahigh-temperature metamorphic terranes; J. Met. Geol. 20 335-350

Scoates J S, Frost C D, Mitchell J N, Lindsley D H and Frost B R 1996 Residual liquid origin for a monzonitic intrusion in a mid-Proterozoic anorthosite complex: the Sybille intrusion, Laramie Anorthosite Complex, Wyoming; Geol. Soc. Am. Bull. 108 1357-1371

Sen G and Dunn T 1994 Dehydration melting of basaltic composition amphibolite at 1.5 and $2.0 \mathrm{GPa}$ : implications for the origin of adakites; Contrib. Mineral. Petrol. 117 394-409

Shaw D M 1972 The origin of the Apslety gneiss, Ontario; Can. J. Earth Sci. 9 18-35

Skjerlie K J and Johnston A D 1993 Fluid-absent melting behavior of an F-rich tonalitic gneiss ar mid-crustal pressures: implications for the generation of anorogenic granites; J. Petrol. 34 785-815

Skjerlie K P and Johnston A D 1996 Vapor-absent melting from 10 to $20 \mathrm{kbar}$ of crustal rocks that contain multiple hydrous phases: implications for anatexis in the deep to very deep continental crust and active-continental margins; J. Petrol. 37 661-691

Skjerlie K P, Patiño Douce A E and Johnston A D 1993 Fluid absent melting of a layered crustal protolith: implications for the generation of anatectic granites; Contrib. Mineral. Petrol. 114 365-378

Spooner C M and Fairbairn H W 1970 Stronitum 87/ Strontium 86 initial ratios in pyroxene granulite terrains; J. Geophys. Res. 75 6706-6713

Springer W and Seck H A 1997 Partial fusion of basic granulites at 5 to 15 kbar: implications for the origin of TTG magmas; Contrib. Mineral. Petrol. 127 30-45

Srikantappa C 1996 The Nilgiri granulites; Gond. Res. Group Mem. 3 185-222

Srikantappa C, Raith M and Speiring B 1985 Progressive charnockitization of a leptynite-khondalite suite in southern Kerala, India - evidence for formation of charnockites through decrease of fluid pressure; J. Geol. Soc. India 26 849-872

Stahle H J, Raith M, Hoernes S and Delfs A 1987 Element mobility during incipient granulite formation at Kabbaldurga, southern India; J. Petrol. 28 803-834

Stern R J 1994 Arc assembly and continental collision in the Neoproterozoic East African orogen: implications for the consolidation of Gondwanaland; Ann. Rev. Earth Planet. Sci. 22 319-351

Subramaniam A P 1959 Charnockites of the type area near Madras: a reinterpretation; Am. J. Sci. 257 $321-353$

Tarney J 1976 Geochemistry of Archaean high-grade gneisses with implications as to the origin and evolution of the Precambrian crust; In: The early history of the Earth (ed) B F Windley (London: Wiley) 405-417

Tarney J and Jones C E 1994 Trace element geochemistry of orogenic igneous rocks and crustal growth models; J. Geol. Soc. London $151855-868$

Tilley C E 1936 Enderbite, a new member of the charnockite series; Geol. Mag. 73 892-939

Touret J L R and Hansteen T H 1988 Geothermobarometry and fluid inclusions in a rock from the Doddabetta charnockite complex, southwest India; Rend. Soc. Ital. Mineral. Petrol. 43 65-82

Vinogradov A, Tugarinov A, Zhygov C, Stapnikova N, Bibikova F and Khorre K 1964 Geochronology of Indian Precambrian; XXII Int. Geol. Cong. Report X 531-567

Warrier U C, Santosh M and Yoshida M 1995 First report of Pan-African Sm-Nd and Rb-Sr mineral isochron ages from regional charnockites of southern India; Geol. Mag. $132253-260$

Watson E B and Harrison M T 1983 Zircon saturation revisited: temperature and composition effects in a variety of crustal magma types; Earth Planet. Sci. Lett. 64 295-304

Weaver B L 1980 Rare-earth element geochemistry of Madras granulites; Contrib. Mineral. Petrol. 71 271-279

Weaver B L, Tarney J, Windley B F, Sugavanan F B and Rao V V 1978 Madras granulites: Geochemistry and P-T conditions of crystallization; In: Archaean Geochemistry (eds) B F Windley and S M Naqvi (Amsterdam: Elsevier) $177-204$

Wendlandt R F 1981 Influence of $\mathrm{CO}_{2}$ on melting of model granulite facies assemblages: a model for the genesis of charnockites; Am. Mineral. 66 1164-1174

White A J R and Chappell B W 1983 Granitoid types and their distribution in the Lachlan Fold Belt, southeastern Australia; Geol. Soc. Am. Mem. 159 21-34

Wilson M J 1989 Igneous Petrogenesis (London: Unwin Hyman)

Wolf M B and Wyllie J P 1994 Dehydration melting of amphibolite at $10 \mathrm{kbar}$ : the effects of temperature and time; Contrib. Mineral. Petrol. 115 309-383

Wolf M B and Wyllie P J 1989 The formation of tonalitic liquids during the vapor-absent partial melting of amphibolite at $10 \mathrm{kbar}$; EOS $\mathbf{7 0} 506$

Zhao J-X, Ellis D J, Kilpatrick J A and McCulloch M T 1997 Geochemical and Sr-Nd isotopic study of charnockites and related rocks in the northern Prince Charles Mountains East Antarctica: implications for charnockite petrogenesis and Proterozoic crustal evolution; Precamb. Res. 81 37-66

Zhou X Q, Bingen B, Demaiffe D, Liégois J-P, Hertogen J, Weis D and Michot J 1995 The 1160 Ma Hidderskog meta-charnockite: implications of this A-type pluton for the Sveconorwegian belt in Vest Agder (SW Norway); Lithos 36 51-66 